\title{
Stromal cells promote anti-estrogen resistance of breast cancer cells through an insulin-like growth factor binding protein 5 (IGFBP5)/B-cell leukemia/lymphoma 3 (Bcl-3) axis
}

\author{
Benjamin Leyh ${ }^{1}$, Angela Dittmer ${ }^{1}$, Theresia Lange ${ }^{1}$, John W. M. Martens ${ }^{2}$, Jürgen \\ Dittmer ${ }^{1}$ \\ ${ }^{1}$ Clinic for Gynecology, Martin Luther University Halle-Wittenberg, Halle/Saale, Germany \\ ${ }^{2}$ Department of Medical Oncology, Erasmus University Medical Center, Rotterdam, The Netherlands \\ Correspondence to: \\ Jürgen Dittmer, e-mail: juergen.dittmer@medizin.uni-halle.de \\ Keywords: stromal cells, anti-estrogen resistance, fulvestrant, mesenchymal stem cells, carcinoma-associated fibroblasts \\ Received: May 12, $2015 \quad$ Accepted: October 09, $2015 \quad$ Published: October 19, 2015
}

\section{ABSTRACT}

There is strong evidence that stromal cells promote drug resistance of cancer. Here, we show that mesenchymal stem cells (MSCs) and carcinoma-associated fibroblasts (CAFs) desensitize ERa-positive breast cancer cells to the anti-estrogen fulvestrant. In search for the mechanism, we found that MSCs and CAFs similarly increased the activity of the PI3K/AKT and the JAK/STAT3 pathways and upregulated the expression of integrin $\beta 1$, IGF1R, HIF1 $a$, CAIX and Bcl-3 in MCF-7 cells. Further analyses revealed that MSCs and CAFs coordinately induce these changes by triggering the downregulation of IGFBP5. Loss of IGFBP5 in MCF-7 cells was an early and long-lasting event in response to MSCs and CAFs and was accompanied by growth stimulation both in the absence and presence of fulvestrant. The growthstimulatory effect in the absence of fulvestrant could be attributed to PI3K/AKT pathway activation and could be mimicked by insulin. The growth-promoting effect in the presence of fulvestrant depended upon the upregulation of Bcl-3. By cRNA microarray analysis we identified additional IGFBP5 targets, of which two (KLHL4 and SEPP1) were inversely regulated by IGFBP5 and Bcl-3. BT474 cells also responded to stromal cells by downregulating IGFBP5 and upregulating the P-AKT, Bcl-3 and IGF1R levels, whereas T47D cells did not show any of these responses. In conclusion, our data suggest that, by targeting IGFBP5 expression in ERa-positive breast cancer cells, such as MCF-7 cells, MSCs and CAFs are able to orchestrate a variety of events, particularly activation of the PI3K/AKT pathway, upregulation of $\mathrm{Bcl}-3$ expression and desensitization to anti-estrogen.

\section{INTRODUCTION}

Breast cancer is the most frequent cancer in women and the leading cause of cancer death in women world-wide [1]. As a heterogeneous disease breast cancer can be divided into subgroups either based on immunochemical or gene expression analysis [2]. Immunochemically, the ER $\alpha$ (estrogen receptor $\alpha$ )-positive breast cancer, the most common breast cancer subtype, can be distinguished from Her2 (human epidermal receptor 2)-positive and triple negative breast cancers (negative for $\mathrm{ER} \alpha, \mathrm{Her} 2$ and progesterone receptor). ER $\alpha$-positive breast cancers can selectively be treated with anti-estrogens or aromatase inhibitors (endocrine therapy). SERM (selective estrogen receptor modulator)-like anti-estrogens, such as tamoxifen, act by blocking ER $\alpha$ activity, SERDs (selective estrogen receptor downregulators), such as fulvestrant, additionally downregulate ER $\alpha$ expression. Aromatase inhibitors interfere with $\mathrm{ER} \alpha$ activity by inhibiting estrogen synthesis, thereby causing estrogen deficiency. Anti-estrogens or aromatase inhibitors significantly reduce breast cancer mortality of patients suffering from ER $\alpha$ positive, but not ER $\alpha$-negative breast cancer confirming the selectivity of these drugs [3]. The success of endocrine therapies, however, is limited by resistance to these drugs (endocrine resistance), either pre-existing (intrinsic 
resistance) or developed in the course of treatment (acquired resistance) $[4,5]$.

Acquired resistance can be facilitated by the tumor stroma [6-8]. Both, extracellular matrix and stromal cells are able to protect cancer cells against drugs. The carcinoma-associated fibroblast (CAF), an important component of the tumor stroma and involved in tumor progression, plays a major role in the acquisition of drug resistance [9]. CAFs, a type of activated fibroblasts, can be generated from different cell types, among which is the mesenchymal stem cell (MSC) [10]. MSCs are commonly residing in the bone marrow and are attracted to wounds and cancer lesions $[11,12]$. Once having entered a cancer lesion, they start interacting with the tumor cells, which most often leads to cancer progression. Like CAFs, MSCs have found to contribute to the acquisition of drug resistance [8, 13].

There are many mechanisms described that could lead to endocrine resistance $[4,5]$. Often, this involves the activation of the survival pathway PI3K (phosphoinositol3-kinase)/AKT [14]. Also the activation of the Ras/Raf/ MEK1/ERK1/2 pathway can be protective against ER $\alpha$ directed drugs. The activation of either pathway can lead to phosphorylation of $\operatorname{ER} \alpha$, allowing $\operatorname{ER} \alpha$ to act independently of estrogen. Both pathways are commonly activated through receptor tyrosine kinases (RTKs) [15]. Of the RTKs, IGF1R (insulin-like growth factor 1 receptor) may be of particular importance for endocrine resistance, as it interacts with $\mathrm{ER} \alpha$ [16] and its agonist IGF-1 (insulin-like growth factor 1) shares with ER $\alpha$ the ability to down-regulate critical growth repressor genes [17]. Regulation of IGF1R activity is complex and is not only controlled by its ligands IGF- 1 and -2 , but also by the IGF inhibitors IGFBP1-6 (IGF binding proteins 1-6) [15]. Interestingly, of these inhibitors, IGFBP2 has been shown to regulate ER $\alpha$ activity [18]. Of note, IGFBPs can also act in an IGF-independent manner [19]. E.g., IGFBP5 has been reported to increase survival of MCF-7 cells in nutrient-poor conditions [20].

Besides RTKs, integrins, such as integrin $\beta 1$, are typical activators of PI3K/AKT and Ras/Raf/MEK1/ ERK1/2 pathways [21] and have also been linked to endocrine resistance [8]. Also the NFאB (nuclear factor of $\kappa \mathrm{B}$ ) pathway, which interferes with ER $\alpha$ activity in multiple ways $[22,23]$, has been implicated in the acquisition of endocrine resistance $[24,25]$. Specifically, Bcl-3 (B-cell leukemia/lymphoma 3), a member of the atypical $\mathrm{I} \kappa \mathrm{B}$ family and regulator of $\mathrm{NF} \kappa \mathrm{B}$ activity in the nucleus [26, 27], has been shown to promote proliferation of MCF-7 cells under estrogen deficiency [28]. Bcl-3 is also linked to breast cancer metastasis [29].

CAFs have been shown to induce resistance to the SERM tamoxifen by activating the PI3K/AKT and/ or Ras/Raf/MEK1/ERK1/2 pathways [30, 31], though other mechanisms have also been reported, which include synthesis of estrogen by CAFs [32] or secretion of ketone bodies and lactate by autophagic CAFs [33]. Little is known about the mechanisms by which MSCs induce resistance to ER $\alpha$-targeting drugs. One report shows that higher expression of the progesterone receptor (PR) may be linked to the ability of MSCs to support growth of ER $\alpha$-positive MCF-7 breast cancer cells under estrogen deficiency [34].

We explored the possibility that MSCs and CAFs may interfere with the SERD-like anti-estrogen fulvestrant (ICI 182,780), which also downregulates ER $\alpha$ protein levels. We found that either stromal cell type promoted growth of ER $\alpha$-positive breast cancer cells, such as MCF7 cells, in the presence of fulvestrant. Searching for the underlying mechanism, we identified Bcl-3 as a major mediator of protection against fulvestrant and found that Bcl-3 was regulated by MSCs and CAFs along with other proteins and phospho-proteins in a coordinated manner through IGFBP5.

\section{RESULTS}

\section{MSCs and CAFs promote resistance of MCF-7 cells to the anti-estrogen fulvestrant}

To show that the anti-estrogen fulvestrant interferes with the activity of MCF-7 breast cancer cells, we examined the effects of fulvestrant on cell growth, on the expression of selected proteins, on spheroid formation and on expression of mesenchymal and stem cell markers. The incubation of MCF-7 cells with fulvestrant at a final concentration of $100 \mathrm{nM}$ for six days strongly reduced growth of individual clones in clonogenic assays (Figure 1A). Along with it, the protein expression of the proliferation marker Ki67 substantially decreased (Figure 1B). Also, as expected, fulvestrant diminished the protein level of $\mathrm{ER} \alpha$ (Figure 1B). Furthermore, fulvestrant downregulated P-AKT and P-ERK1/2 levels (Figure 1B) suggesting that fulvestrant exerts an inhibitory effect on the PI3K/AKT- and the Ras/Raf/MEK/ERK1/2 pathways. Fulvestrant also interfered with cell aggregation in $3 \mathrm{D}$ suspension cultures and led to the generation of smaller spheroids (Figure 1C). In addition, fulvestrant significantly induced the RNA expression of the mesenchymal proteins vimentin, fibronectin and ACTA2 ( $\alpha$-smooth muscle actin) und induced the expression of a couple of stem cell markers, such as PROCR, ABCG2 (ATP binding cassette subfamily G2) and ALDH3A1 (aldehyde dehydrogenase 3 family, member A1) (Figure 1D) while reducing the expression of the stem cell marker CD44. This may suggest that fulvestrant promotes the expansion of a pool of cells of a more mesenchymal phenotype, which may be more resistant to fulvestrant.

Next, we studied the effects of MSCs and CAFs on MCF-7 growth in the presence and absence of fulvestrant. When MCF-7 cells were co-cultured with MSCs at a ratio of 10:1 for five days and compared to MCF-7 cells grown 

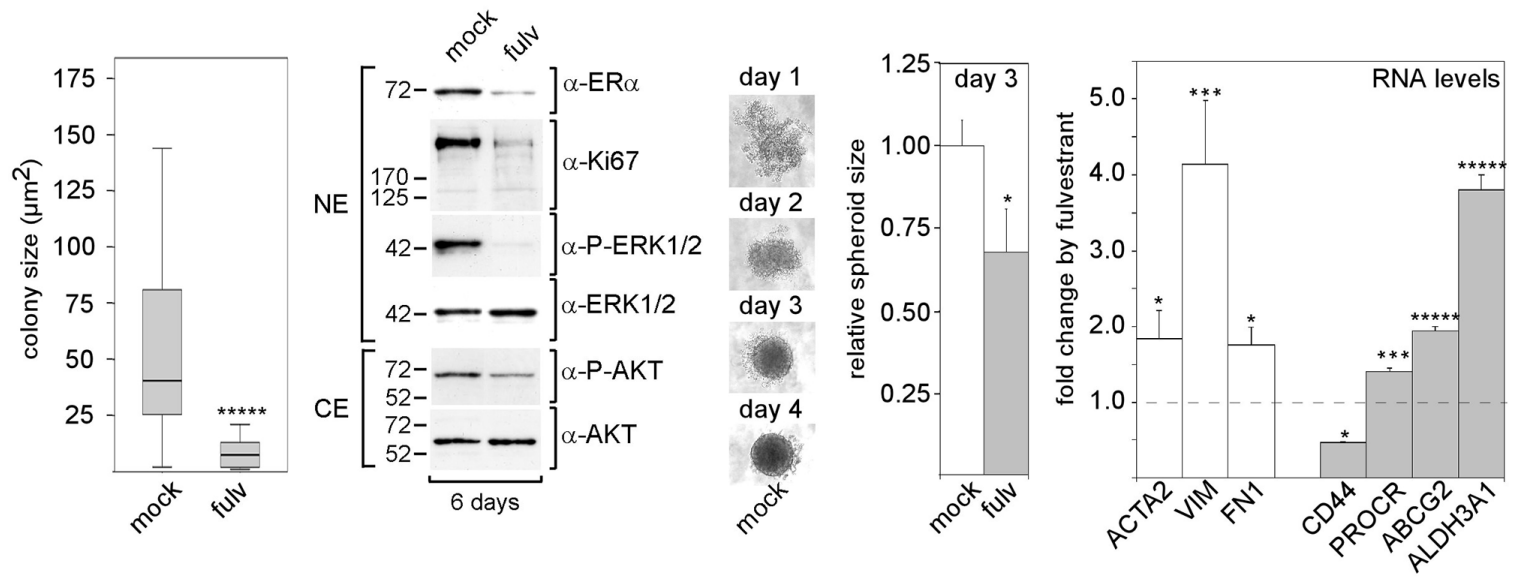

$\mathrm{E}$
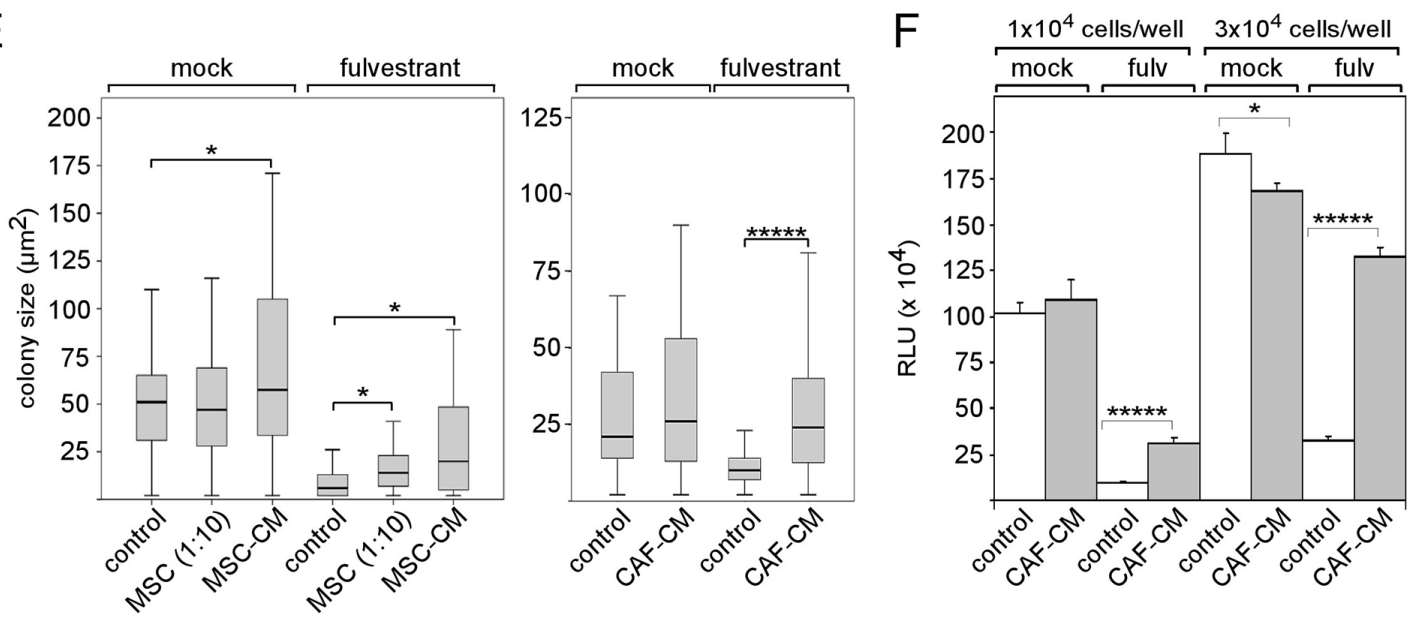

G
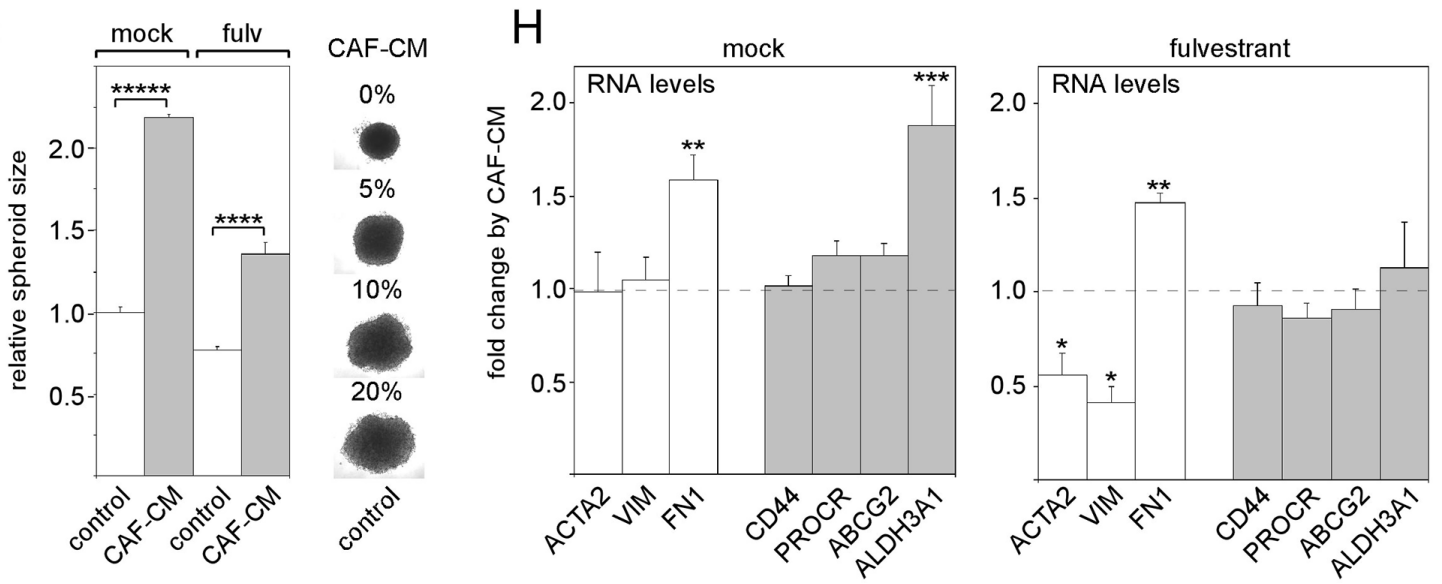

Figure 1: MSCs and CAFs promote growth of MCF-7 cells in the presence of fulvestrant. Effect of $100 \mathrm{nM}$ fulvestrant on A. colony size of MCF-7 cells in the clonogenic assays, B. expression of ER $\alpha$, Ki67, P-ERK1/2 and P-AKT levels in Western blot analysis, C. spheroid formation and D. RNA expression of mesenchymal markers (ACTA, VIM, FN1) and stem cell markers (CD44, PROCR, ABCG2, ALDH3A1). E, F. Effects of MSCs, MSC-CM and CAF-CM on MCF-7 cell growth in the presence and absence of fulvestrant. Cell growth was either determined by measuring the sizes of individual clones in the clonogenic assay (E) or by the ATP-based growth assay (F). G, H. Effect of CAF-CM on (G) spheroid size in the presence and absence of fulvestrant and (H) on the RNA levels of mesenchymal and stem cell markers in the absence and presence of fulvestrant. In (A, E), the data of a representative experiment are shown, in (D, F-H), each bar represents the mean value \pm S.D. of at least three independent experiments. Statistical analysis for the clonogenic assay was performed by the Wilcoxon test (A, E). Other statistical analyses were done by using the student's $t$-test. ACTA $=\alpha$-smooth muscle actin, $\mathrm{VIM}=$ vimentin, FN1 = fibronectin-1, ABCG2 = ATP binding cassette subfamily G2), ALDH3A1 (aldehyde dehydrogenase 3 family, member $\mathrm{A} 1$ ), $\mathrm{NE} / \mathrm{CE}=$ nuclear/cytosolic protein extract, $\mathrm{RLU}=$ relative light units. 
alone, average colony size was significantly increased in the presence, but not in the absence of fulvestrant (Figure 1E). Growing MCF-7 cells in growth medium that contains $20 \%$ conditioned medium from MSCs (20\% MSC$\mathrm{CM}$ ) or from CAFs (20\% CAF-CM) had similar strong promoting effects on the growth of individual colonies in the presence of fulvestrant (Figure 1E). Unlike MSCs, $20 \%$ MSC-CM or 20\% CAF-CM had also some moderate effects on colony growth in the absence of fulvestrant. In a different set of experiments with an ATP-based growth assay, cell growth was monitored after cells had been seeded at higher cell density that prevented the formation of individual colonies, but still left sufficient space for cell growth over a growth period of five days. Also under these conditions, CAF-CM was able to strongly increase cell growth in the presence of fulvestrant, but failed to promote growth or even reduced growth in the absence of fulvestrant (Figure 1F).

We next sought to analyze whether stromal cells also affect spheroid formation. We found that 20\% CAF$\mathrm{CM}$ increases the size of spheroids both in the presence and absence of fulvestrant (Figure 1G). However, these effects did not seem to be the result of increased MCF7 cell growth. It rather seemed that CAF-CM causes the MCF-7 cells in the spheroids to be more loosely packed (Figure 1G) This may be the result of a reduced cell-cell contact as was found in spheroids that MCF-7 cells had formed in the presence of MSCs [35]. Next, we examined whether CAF-CM affected the expression of mesenchymal and stem cell markers. Of the selected markers, only fibronectin-1 showed increased RNA levels upon treatment with CAF-CM both in the presence and absence of fulvestrant (Figure $1 \mathrm{H}$ ). In the absence of fulvestrant, also the expression of ALDH3A1 was increased by CAF-CM.

Collectively, these data suggest that MSCs and CAFs secrete certain factors that protect MCF-7 cells from the growth-inhibitory effect of fulvestrant. Since most of the selected mesenchymal and stem cell markers were not affected by CAF-CM, it is unlikely that the stroma cellinduced protective effect against fulvestrant is mediated by an increase in the stem/progenitor cell pool of the MCF-7 cells.

\section{MSC- and CAF-CM interfere with the activities of signaling pathways and the expression of proteins involved in drug resistance}

To identify the mechanism that underlies the $\mathrm{MSC} / \mathrm{CAF}$-induced fulvestrant resistance, we examined the expression of a number of proteins, integrin $\beta 1$, IGF1R and Bcl-3, and the activities of a number of signaling pathways, the PI3K/AKT-, the Ras/Raf/MEK1/ ERK1/2-pathways, the JAK2 (janus kinase 2)/STAT3 (signal transducer and activator of transcription 3) and the hypoxia-regulated pathway. All these proteins and signaling pathways have been associated with drug resistance and/or deregulation of $\mathrm{ER} \alpha$ activity $[14,16,17$, $21,28,36,37]$. To study the activities of the four pathways we determined the phospho-protein levels of AKT, ERK1/2, STAT3 and the plasma-membrane level of the hypoxia-regulated protein CAIX (carbon anhydrase) [38] by Western blot analysis. To mimic potential effects on the PI3K/AKT- and the Ras/Raf/MEK1/ERK1/2- pathways by stromal cells we used insulin, shown to induce these pathways in MCF-7 cells [39]. To recapitulate potential stromal cell effects on the hypoxia-regulated pathway we used the hypoxia-mimetic agent $\mathrm{CoCl}_{2}$.

We found that a 3-day-incubation of $\mathrm{MCF}-7$ cells with $20 \%$ MSC- or $20 \%$ CAF-CM similarly increased phosphorylation of AKT and STAT3, while having no effect on ERK1/2 phosphorylation (Figure 2A). Both CMs also increased plasma membrane abundance of CAIX. As shown with CAF-CM, also the level of CAIXregulator HIF1 $\alpha$ (hypoxia inducible factor $1 \alpha$ ) was raised (Figure 2B). This suggests that MSC- and CAFCM activate the PI3K/AKT-, the JAK2/STAT3- and the hypoxia-regulated pathway, whereas it had no effect on the Ras/Raf/MEK/ERK1/2 pathway. However, limiting the duration of incubation with CAF-CM to overnight led to an increase in the P-ERK1/2 levels (Supplementary Figure S1) suggesting that the activation of the Ras/Raf/ MEK/ERK1/2 pathway by stromal cell CM is temporary. MSC- and CAF-CM also increased the plasma membrane levels of IGF1R and integrin $\beta 1$ and the nuclear protein level of Bcl-3 (Figure 2A). Of note, the two Bcl-3-specific protein bands likely correspond to a phosphorylated and the non-phosphorylated form of Bcl-3, of which both are able to regulate transcription [40]. Insulin could mimic the effect of MSC- and CAF-CM on P-AKT and integrin $\beta 1$ (Figure 2A). Also, like stromal cell-CM, insulin induced a temporary increase in ERK1/2 phosphorylation (Supplementary Figure S1). However, unlike stromal cellCM, insulin did not modulate the levels of P-STAT3, Bcl3, IGF1R and CAIX (Figure 2A). The hypoxia-mimetic agent $\mathrm{CoCl}_{2}$, that strongly induced the expression of HIF $1 \alpha$ protein und CAIX in MCF-7 cells (Figure 2B), shared with insulin the ability to increase the integrin $\beta 1$ level and also, like insulin, had no effect on $\mathrm{Bcl}-3$ expression (Figure 2C). However, unlike insulin, $\mathrm{CoCl}_{2}$ recapitulated the effect of MSC- and CAF-CM on CAIX, P-STAT3, IGF1R expression, while having no effect on P-AKT (Figure 2C). Consequently, when combined, insulin and $\mathrm{CoCl}_{2}$ could mimic most of the effects of MSC- and CAF$\mathrm{CM}$. The only two tested stroma cell-responsive proteins whose expression remained unchanged in response to a combined treatment with insulin and $\mathrm{CoCl}_{2}$ were $\mathrm{Bcl}-3$ and IGF1R.

To test whether Bcl-3 and IGF1R expression are linked, we downregulated $\mathrm{Bcl}-3$ by a Bcl-3-specific siRNA ( $\mathrm{siBcl} 3$ ). In fact, siBcl3 attenuated the effect of CAF-CM on the expression of IGF1R and also on that of CAIX, while it strongly increased the integrin $\beta 1$ level 
A

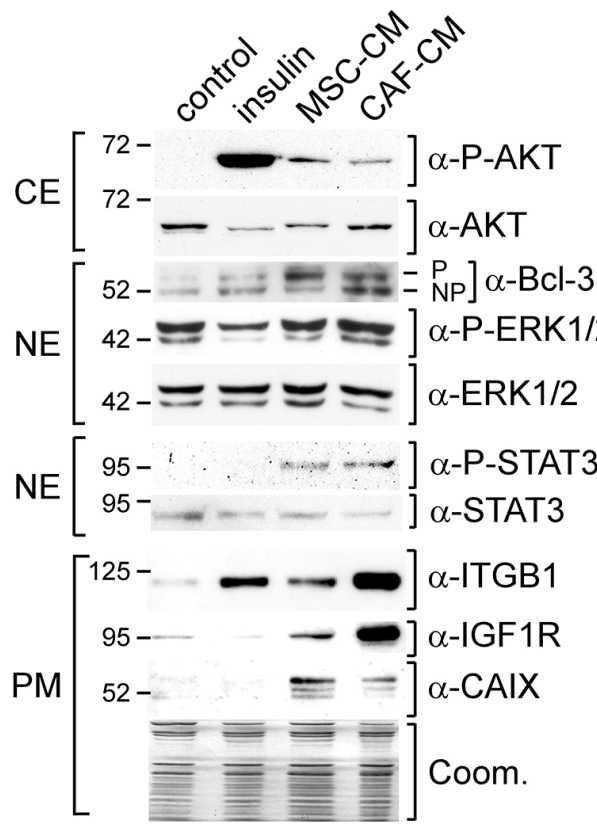

D

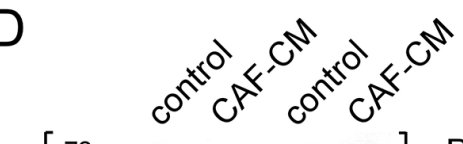

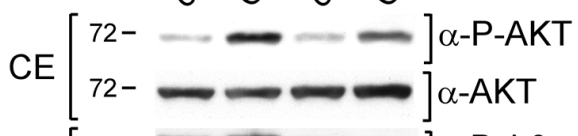

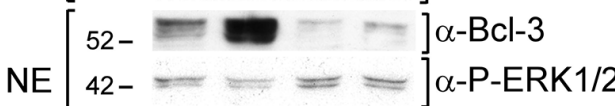

$42-=-\cdots \alpha-E R K 1 / 2$

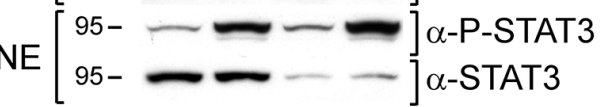

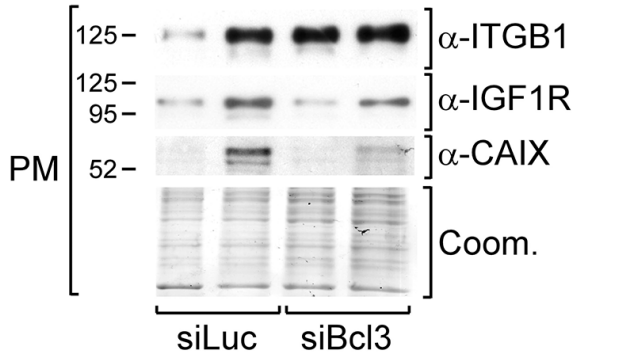

B

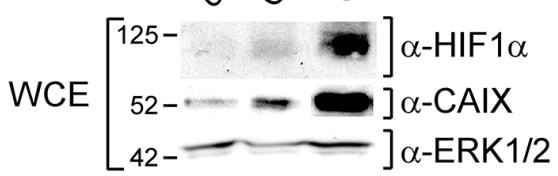

C

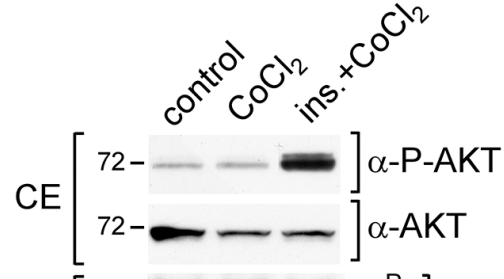

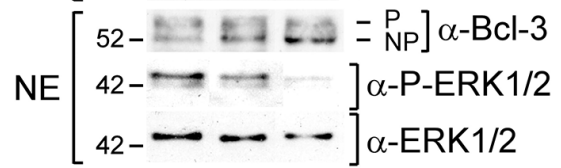

$\mathrm{NE}\left[\begin{array}{l}95--\cdots] \alpha-\text { P-STAT3 } \\ 95--] \alpha-\text { STAT3 }\end{array}\right.$

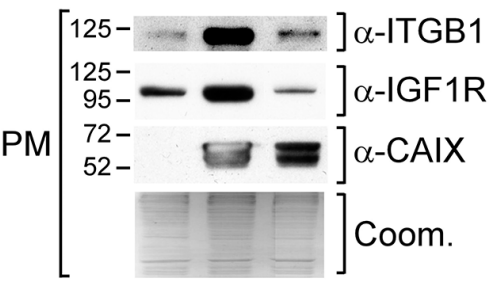

Figure 2: MSC- and CAF-CM upregulate the activities of signaling pathways and expression of proteins relevant in the acquisition of drug resistance. Western blot analyses of the indicated proteins and phospho-proteins were performed after MCF7 cells were incubated with insulin, $100 \mu \mathrm{M} \mathrm{CoCl}$ insulin plus $\mathrm{CoCl}_{2}$ (ins./ $\mathrm{CoCl}_{2}$ ), MSC- or CAF-CM and/or transfected with siBcl3, siSTAT3 or with the control siRNA siLuc. Depending on the cellular location of the protein or phospho-protein, either the cytosolic (CE), nuclear (NE) or plasma membrane (PM) extract was used for the analysis A-C, E. For the visualization of the HIF $1 \alpha$ protein, whole cell extracts (WCE) were prepared by lysing cells in RIPA buffer B. To check for equal loading of plasma membrane proteins, proteins remaining in the gel after blotting were stained with Coomassie Blue (Coom.). 
(Figure 2D). This suggests that stromal cells induce the expression of IGF1R and also CAIX by upregulating the Bcl-3 level. Since STAT3 can regulate Bcl-3 expression in prostate cancer [41], we wondered whether STAT3 and Bcl-3 expression are also linked in MCF-7 cells. However, knock-down of STAT3 by a STAT3-specific siRNA (siSTAT3) only slightly reduced CAF-CM-induced Bcl-3 expression and, with it, also weakly diminished the levels of IGF1R and CAIX (Figure 2E). Hence, activation of STAT3 by stromal cell CM is unlikely to be the major cause for $\mathrm{CM}$-induced $\mathrm{Bcl}-3$ expression, although it may contribute to it.

\section{MSCs and CAFs coordinately modulate signaling pathways and protein expression by downregulating the IGFBP5 level}

Next we analyzed the involvement of the IGF1Rdependent signal pathway in the MSC- and CAFinduced effects for two reasons. One, MSC- and CAFCM upregulated the IGF1R level along with the P-AKT level. Two, blockage of IGF1R-dependent signaling by the IGF1R-specific inhibitor PQ401 strongly reduced the phosphorylation status of AKT (Supplementary Figure S1). suggesting that IGF1R is a major driver of the PI3K/AKT pathway in MCF-7 cells. IGF1R activity is regulated by its activators IGF1 and 2 and by the IGFbinding proteins IGFBP1-6 which regulate the activity of the IGFs. Besides their IGF-dependent activities, IGFBPs also show IGF-independent effects [19]. Therefore, in theory, by modulating IGFBP expression, stromal cells could modulate IGF-dependent and -independent effects at the same time. Hence, we analyzed whether CAF-CM is able to induce changes in the expression of any of the IGFs and the IGFBPs by quantitative RT-PCR. We also included IGFBP7 in our analysis, since IGFBP7 was shown to bind to IGF1R and to block its activation by IGFs [42]. When we incubated MCF-7 cells with increasing amounts of CAF-CM (1, 5 and 20\%), the mRNA level of IGF2, which showed higher basal levels than IGF1 (data not shown), increased up to $\sim 15$-fold (Figure 3A). Of the IGFBPs, IGFBP5, 6 and 7 showed a dose-dependent decline in their expression in response to $\mathrm{CAF}-\mathrm{CM}$, whereas the level of IGFBP3 increased in the presence of CAF-CM (Figure 3B). Of all IGFBPs, IGFBP5 was expressed at the highest basal level in MCF-7 cells, followed by IGFBP4 and IGFBP2 (data not shown). The other four IGFBPs were much less abundant with IGFBP1 showing the lowest (barely detectable) expression. Therefore, of all CAF-CMinduced changes in IGFBP expression, the changes in the IGFBP5 levels should be most relevant for IGF1R activity. Hence, we focused our further analysis on IGFBP5. We found that the change in the IGFBP5 level by CAF-CM was an early event. Four hours of incubation of MCF7 cells with CAF-CM was sufficient to bring IGFBP5 expression down to $\sim 50 \%$ of its original level (Figure $3 \mathrm{C}$ ).
In addition, the suppressive effect of CAF-CM on IGFBP5 levels was long-lasting.

To analyze whether downregulation of IGFBP5 is sufficient to induce the observed effects of MSCs and CAFs on MCF-7 cells, MCF-7 cells were treated with an IGFBP5-specific siRNA (siIGFBP5). siIGFBP5 decreased IGFBP5 levels by $\sim 4$-fold, which was comparable to the decline in IGFBP5 expression as observed in response to CAF-CM (Figure 4A). Of note, siSTAT3 had no effect on IGFBP5 expression suggesting that stromal cell-induced activation of the JAK2/STAT3 pathway is not responsible for the downregulation of the IGFBP5 level. A comparison of the effects of silGFBP5 and CAF-CM revealed that siIGFBP5 was as effective as CAF-CM to upregulate the levels of P-AKT, Bcl-3 and CAIX (Figure 4B). In addition, siIGFBP5 slightly increased the levels of IGF1R and P-STAT3, whereas SiIGFBP5 alone failed to modulate the expression of integrin $\beta 1$. Interestingly, treatment of MCF-7 cells with both CAF-CM and siIGFBP5, which reduced IGFBP5 expression to $\sim 7 \%$ of its original level (Figure 4A), generated the highest levels of Bcl-3, IGF1R, CAIX, integrin $\beta 1$ and P-STAT3 (Figure 4B). These data suggest that stromal cells can induce most of the observed effects on signaling pathway activity and protein expression by simply downregulating IGFBP5 expression.

\section{Bcl-3 is involved in stromal cell-induced fulvestrant resistance}

The strong effect of siIGFBP5 on the Bcl-3 level prompted us to further analyze the link between IGFBP5 and Bcl-3 expression. First, we wanted to confirm that MSCs also downregulate the IGFBP5 level while upregulating that of Bcl-3. For this, we used two MSC isolates and either co-cultured MSCs with MCF-7 cells in a ratio of 1:50 or added 20\% MSC-CM to the MCF-7 cells. Under all conditions, both MSC isolates significantly downregulated IGFBP5 RNA expression and, at the same time, upregulated the Bcl-3 RNA level (Figure 4C). We next compared IGFBP5 levels with those of Bcl-3 in 76 RNA samples isolated from MCF-7 cells either treated with CAF-CM (closed circles, $N=32$ ) or left untreated (open circles, $N=44$ ). The data suggest an exponential, inverse correlation between the expression of both genes such that changes in IGFBP5 expression have the most profound effects on Bcl-3 expression when IGFBP5 levels are low (Figure 4D). The hypothesis that IGFBP5 and $\mathrm{Bcl}-3$ expression are linked is further supported by the observation that CAF-CM modulated Bcl-3 mRNA and protein expression early (Figure 4E, 4F), just as seen with IGFBP5 (Figure 3C).

Having established that downregulation of IGFBP5 allows MSCs and CAFs to coordinate a number of events, we explored the possibility that a decline in the IGFBP5 level also affects colony growth of MCF-7 cells. By using siIGFBP5, we found that a decrease in IGFBP5 expression 
A

B
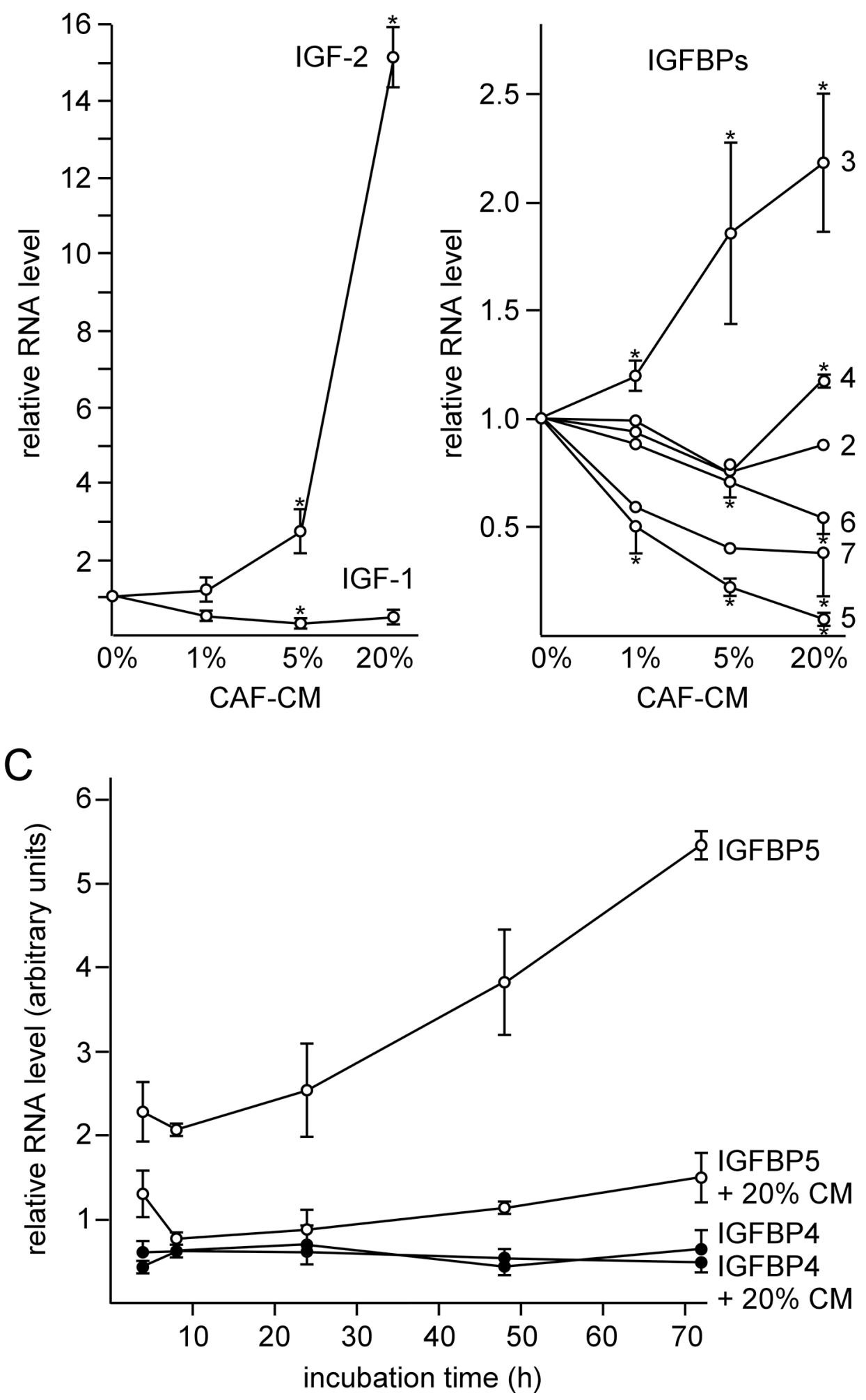

Figure 3: CAF-CM induces the downregulation of IGFBP5 expression. A, B. RT-PCR analyses of RNA isolated from MCF-7 cells after 2-day-exposure to $0,1,5$ or 20\% CAF-CM for the abundance of IGF-1/-2 specific mRNAs (A) and IGFBP1-7-specific mRNAs (B). C. Time-course study to measure changes in IGFBP4/5 mRNA levels in MCF-7 cells within 4-72 h after addition of 20\% CAF-CM or no addition of CAF-CM. 


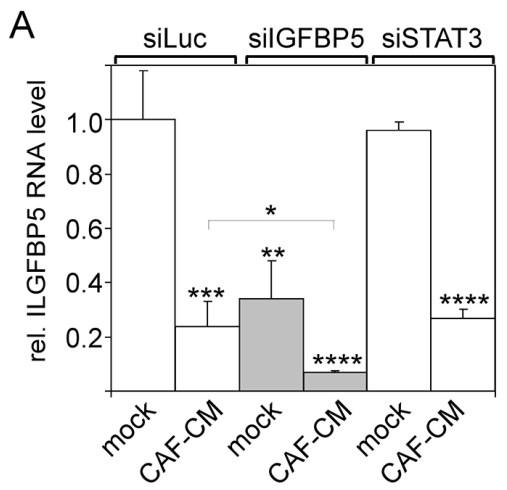

B

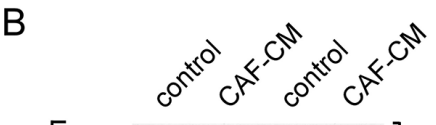

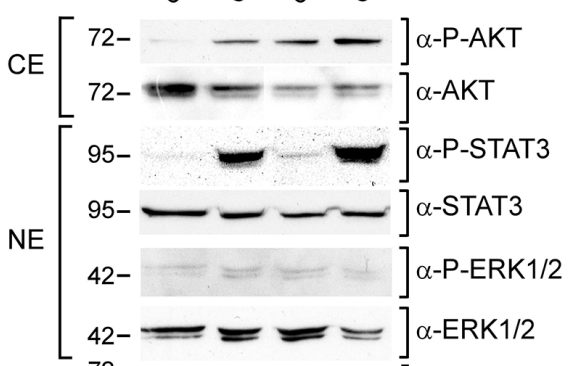

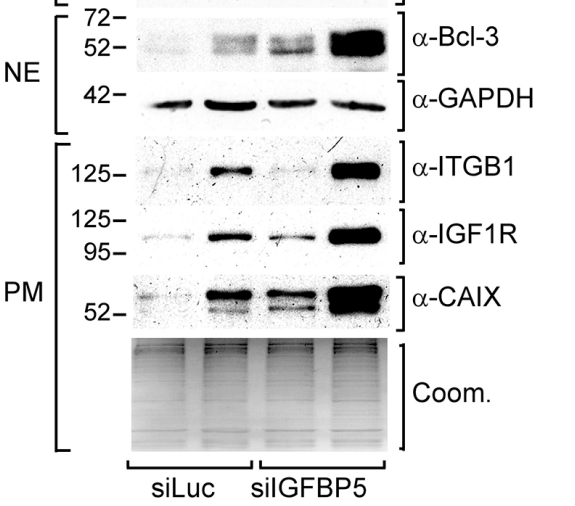

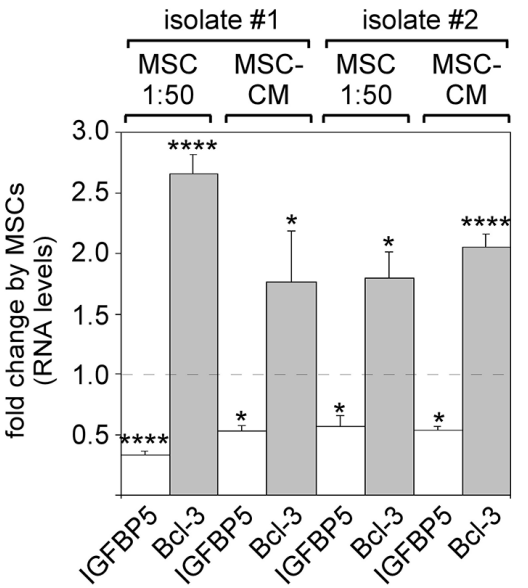

$\mathrm{D}$

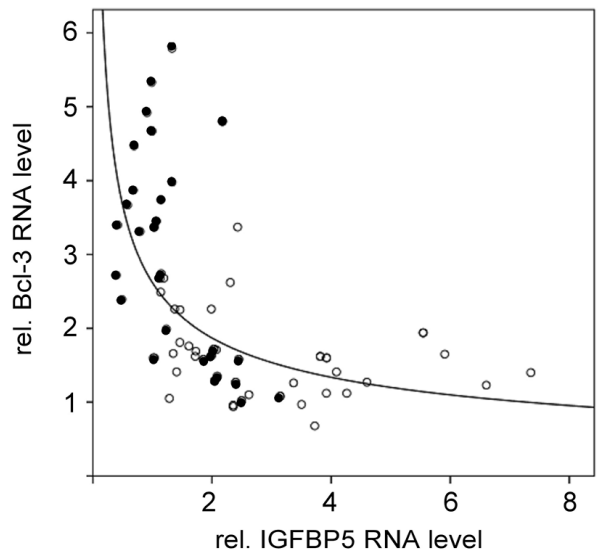

$E$

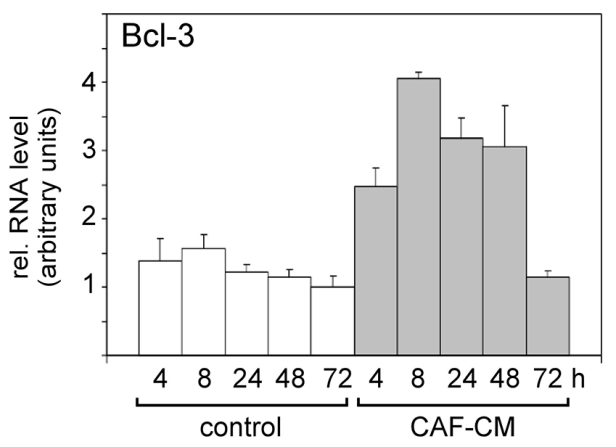

$\mathrm{F}$

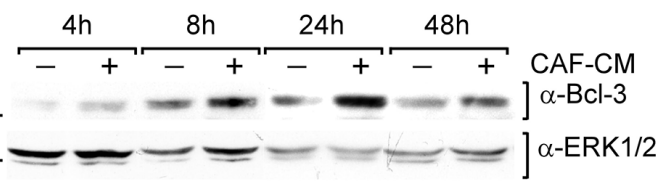

Figure 4: Knock-down of IGFBP5 mimics most of the CAF-CM-induced effects on signaling pathways and protein expression. A. RT-PCR analysis of IGFBP5 mRNA levels in MCF-7 cells transfected with siIGFBP5, siSTAT3 or siLuc (control siRNA) followed by treatment with CAF-CM or no treatment. B. Western blot analyses of levels of stromal cell-regulated proteins and phosphoproteins after treatment of MCF-7 cells with siIGFBP5 or siLuc in the presence or absence of CAF-CM (CE $=$ cytosolic extract, $\mathrm{NE}=$ nuclear extract, $\mathrm{PM}=$ plasma membrane extract). To check for equal loading of plasma membrane proteins, proteins remaining in the gel after blotting were stained with Coomassie Blue (Coom.) C. Effects of two different human MSCs isolates on IGFBP5 and Bcl-3 levels in MCF-7 cells. Either MSCs were co-cultured with MCF-7 cells in a ratio of 1:50 or 20\% MSC-CM was added to the MCF-7 cells. D. RT-PCR analyses of RNAs isolated from MCF-7 cells treated with CAF-CM (•) or from untreated MCF-7 cells (०) for IGFBP5 and Bcl-3 mRNA levels. E, F. Comparison of the Bcl-3 mRNA RNA (E) and protein (F) levels in the presence and absence of CAF-CM in a time course experiment. For each time point, the difference in Bcl-3 expression between control cells and CAF-CM-treated cells is statistically significant as determined by paired sample student's $t$-test. In (A, D, F), each bar represents the mean value \pm S.D. of at least three independent experiments. 
resulted in an increase in average colony size both in the absence and presence of fulvestrant (Figure 5A). To check whether the PI3K/AKT pathway was responsible for these effects, we repeated the experiments with insulin. While insulin was able to significantly increase average colony growth in the absence of fulvestrant, it failed to do so in the presence of fulvestrant (Figure 5B). This suggests that the effect of silGFBP5 on growth in the presence of fulvestrant was not caused by the activation of the PI3K/AKT pathway. Next, we tested whether Bcl-3 may affect MCF-7 cell growth. Strikingly, siBcl-3 did not significantly alter cell growth in the absence of fulvestrant,
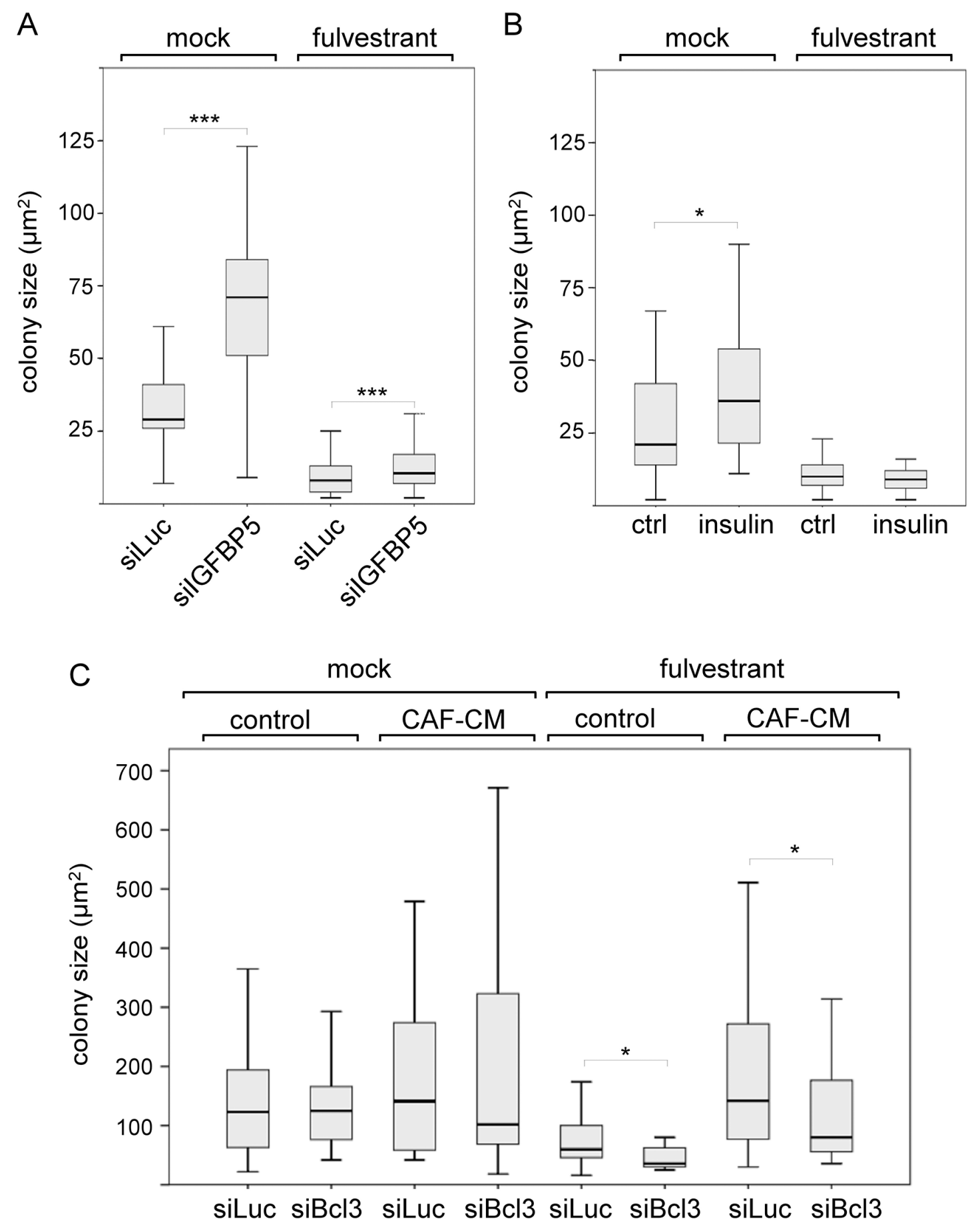

Figure 5: Bcl-3 knock-down specifically interferes with MCF-7 growth in the presence of fulvestrant. A, C. Effect of siIGFBP5 (A), siBcl3 (C) and siLuc (A, C) on the size of individual colonies of MCF-7 cells in the clonogenic assay in the presence or absence of fulvestrant and in the presence or absence of CAF-CM. B. Clonogenic assays performed with insulin- or mock-treated MCF-7 cells. Statistical analyses were carried out by using the Wilcoxon test. 
but selectively reduced growth in the presence of fulvestrant, most profoundly in the presence of CAF-CM (Figure 5C). This suggests that the increased expression of Bcl-3 caused by stromal cell-induced downregulation of IGFBP5 is at least partially responsible for stromal cellmediated fulvestrant resistance.

\section{Downregulation of IGFBP5 has an impact on the expression of stromal cell-regulated genes}

We next sought to identify stromal cell-regulated MCF-7 cell genes that are inversely regulated by IGFBP5 and Bcl-3. For this reason, we performed two sets of independent cRNA microarray experiments comparing the transcripts of MCF-7/MSC co-cultures (ratio: 50 to 1) with those in MCF-7 cells alone. The expression of a total of $253 \mathrm{mRNA}$ species was changed by $\geq 2$-fold in the presence of MSCs (Supplementary Table S2). Of these, 18 mRNA species showed reduced expression in the MCF-7/MSC co-cultures. The much higher number of upregulated RNA species could at least partly be explained by the presence of MSC-derived RNAs, such as PAI-1 (plasminogen activator inhibitor-1)-specific, ZEB-1 (zinc finger E-box binding homeobox 1)-specific or CD90-specific RNAs, that are strongly expressed in MSCs, but weakly or not expressed in MCF-7 cells (data not shown). For further analysis, we focussed on the RNAs that showed lower expression in the MCF-7/ MSC co-cultures, since, in theory, they should derive from MCF-7 cells. Of the 18 downregulated mRNA species, 17 coded for known genes. For 13 of these 17 genes MSCdependent changes could be confirmed by Q-RT-PCR assays. Of these 13 genes, two genes (CDSN and CALCR) showed very low expression and were therefore excluded from further analysis. The remaining 11 genes are listed in Table 1. Nine of these genes were also downregulated in $\mathrm{MCF}-7 / \mathrm{MSC}$ co-cultures when cells were kept in 3D suspension cultures that led to spheroid formation. Ten of these genes showed also reduced expression in MCF7/MSC co-cultures when MSCs and MCF-7 cells were separated by a $0.4 \mu \mathrm{m}$ filter that prevented direct cell-cell contact, but allowed paracrine effects. MSC-CM induced the level of nine of these genes, while $\mathrm{CAF}-\mathrm{CM}$ reduced the expression of all eleven genes. Interestingly, most of these genes were also responsive to insulin and $\mathrm{CoCl}_{2}$.

Collectively, these data suggest that these eleven genes are regulated by MSCs and CAFs through soluble factors that these stromal cells secret, just as was found for the stroma cell-mediated regulation of IGFBP5 and Bcl-3.

Examining the expression of these genes in the presence of silGFBP5 and siBcl3, we found that two genes (SEPP1 and KLHL4) were inversely regulated by siIGFBP5 and siBcl3. Like stromal cells, siIGFBP5 significantly downregulated the expression of these two genes, while siBcl3 upregulated their levels. Moreover, the expression of KLHL4 and SEPP1 correlated well with that of IGFBP5 (Figure 6A, 6C) and showed an inverse correlation to that of Bcl-3 (Figure 6B, 6D). As a control we used KLK11. This stromal cell-regulated gene was neither affected by siIGFBP5 nor by siBcl-3 (Table 1). Nor did the expression of this gene show any correlation with the expression of IGFBP5 or Bcl-3 (Figure 6E, 6F).

These data suggest that two MSC/CAF-regulated genes, KLHL4 and SEPP1, are inversely regulated by IGFBP5 and Bcl-3.

\section{Stromal cell-induced downregulation of IGFBP5 in other breast cancer cells}

We next examined whether stromal cells may be able to modulate signal pathway activities and protein expression also in other ER $\alpha$-positive breast cancer cell lines (BT474 and T47D) in a similar way as in MCF-7 cells and whether they may also affect cell growth in the presence of fulvestrant. As seen with MCF-7 cells, BT474 cells responded to CAF-CM by a significant decrease in the IGFBP5 RNA expression and a significant rise in the Bcl-3 RNA level (Figure 7A). CAF-CM also increased $\mathrm{Bcl}-3$ protein expression and upregulated the levels of the P-AKT and P-STAT3 (Figure 7B). However, in contrast to MCF-7 cells, BT474 cells failed to increase the expression of integrin $\beta 1$ and IGF1R in response to CAF-CM. Of note, insulin also failed to increase the integrin $\beta 1$ level in BT474 cells (data not shown). By being much higher in BT474 cells than in MCF-7 cells, the level of integrin $\beta 1$ may have already reached its maximum value in its basal state. It is also noteworthy that the CAIX protein could not be detected by Western blot analysis, even when cells were treated with $\mathrm{CoCl}_{2}$ (data not shown). In an ATP-based growth assay, CAF-CM significantly promoted BT474 growth in the presence of fulvestrant, though the effect was less pronounced than that seen with MCF-7 cells. Importantly, no effect of CAF-CM could be observed on BT474 cell growth in the absence of this drug (Figure 7C). Of note, clonogenic assay could not be performed with BT474 cells, since BT474 cells did not survive when seeded at low density.

Collectively, these data indicate that BT474 cells behave similar to MCF-7 cells in terms of their responses to CAF-CM. Like MCF-7 cells, BT474 cells show higher growth activity in the presence of fulvestrant, lower expression of IGFBP5, higher levels of Bcl-3 and an increase in the PI3K/AKT pathway activity suggesting that CAF-CM induces these changes in both cell lines through the same mechanism.

In contrast to BT474 and MCF-7 cells, T47D cells were quite unresponsive to $\mathrm{CAF}-\mathrm{CM}$ in terms of changes in protein expression and pathway activities (Figure 7D, 7E). CAF-CM only increased the P-STAT3 levels in T47D cells (Figure 7E). Of note, Bcl-3 protein could not be detected (data not shown). To check whether the PI3K/AKT and HIF1 $\alpha /$ CAIX pathways are functional in 
Table 1: Relative expression of selected MSC/CAF-responsive genes in MCF-7 cells under different conditions

gene

relative RNA expression*

\begin{tabular}{|c|c|c|c|c|c|c|c|c|c|}
\hline $\begin{array}{c}\text { MCF7/ } \\
\text { MSC } \\
\text { co- }\end{array}$ & $\begin{array}{c}\text { MCF7/ } \\
\text { MSC co- } \\
\text { culture }\end{array}$ & $\begin{array}{c}\text { MCF7/ } \\
\text { MSC } \\
\text { TW (0.4 }\end{array}$ & $\begin{array}{c}\text { MSC- } \\
\text { CM } \\
\mathbf{2 0 \%}\end{array}$ & $\begin{array}{c}\text { CAF- } \\
\text { CM } \\
20 \%\end{array}$ & $\begin{array}{l}\text { silGFBP5 } \\
\text { vs. siLuc }\end{array}$ & $\begin{array}{c}\text { siBcl3 } \\
\text { vs. siLuc }\end{array}$ & $\begin{array}{l}\text { siSTAT3 } \\
\text { vs. siLuc }\end{array}$ & $\begin{array}{c}\text { Insulin } \\
\text { vs. mock }\end{array}$ & $\begin{array}{c}\mathrm{CoCl}_{2} \\
\text { vs. mock }\end{array}$ \\
\hline
\end{tabular}

culture 10:1, 3D $\mu \mathrm{m}) 10: 1$

50:1, (\#)

\begin{tabular}{|c|c|c|c|c|c|c|c|c|c|c|}
\hline 4 & $\begin{array}{l}\mathbf{0 . 3 5} \pm \\
\mathbf{0 . 1 9}(p= \\
0.018)\end{array}$ & $\begin{array}{l}\mathbf{0 . 0 6} \pm \\
\mathbf{0 . 0 1}(p= \\
0.02)\end{array}$ & $\begin{array}{l}0.14 \pm \\
0.03(p= \\
0.0026)\end{array}$ & $\begin{array}{l}0.28 \pm \\
0.05(p= \\
0.0055)\end{array}$ & $\begin{array}{l}0.26 \pm \\
0.08(p= \\
0.0033)\end{array}$ & $\begin{array}{l}0.49 \pm \\
0.26(p= \\
0.036)\end{array}$ & $\begin{array}{l}\mathbf{2 . 4 6} \pm \\
\mathbf{0 . 6 8}(p= \\
0.022)\end{array}$ & $\begin{array}{l}0.72 \pm \\
0.09(p= \\
0.0052)\end{array}$ & $\begin{array}{l}0.50 \pm \\
0.04(p= \\
0.011)\end{array}$ & $\begin{array}{l}\mathbf{0 . 5 9} \pm \\
\mathbf{0 . 1 1}(p= \\
0.030)\end{array}$ \\
\hline $\mathbf{F}$ & $\begin{array}{l}\mathbf{0 . 3 9} \pm \\
\mathbf{0 . 2 0}(p= \\
0.013)\end{array}$ & $\begin{array}{l}\mathbf{0 . 0 2}(p= \\
0.0034)\end{array}$ & $\begin{array}{l}\mathbf{0 . 1 7}(p= \\
0.050)\end{array}$ & $\begin{array}{l}0.05(p= \\
0.3)\end{array}$ & $\begin{array}{l}\mathbf{0 . 0 1}(p< \\
0.0001)\end{array}$ & $\begin{array}{l}\mathbf{0 . 1 1}(p= \\
0.03)\end{array}$ & $\begin{array}{l}\mathbf{2 . 6 6} \pm \\
\mathbf{0 . 3 2}(p= \\
0.0018)\end{array}$ & $\begin{array}{l}\mathbf{0 . 1 6}(p= \\
0.027)\end{array}$ & $\begin{array}{l}0.47 \pm \\
0.19(p= \\
0.0087)\end{array}$ & $\begin{array}{l}\mathbf{0 . 3 1} \pm \\
\mathbf{0 . 0 6}(p= \\
0.0015)\end{array}$ \\
\hline 126 & $\begin{array}{l}0.39 \pm \\
0.24(p= \\
0.0038)\end{array}$ & $\begin{array}{l}0.53 x \\
0.10(p= \\
0.037)\end{array}$ & $\begin{array}{l}0.24 \pm \\
0.16(p= \\
0.008)\end{array}$ & $\begin{array}{l}0.38 \pm \\
0.15(p= \\
0.0026)\end{array}$ & $\begin{array}{l}0.47 \pm \\
0.06(p= \\
0.0028)\end{array}$ & $\begin{array}{l}\mathbf{0 . 1 5}(p= \\
0.0086)\end{array}$ & $\begin{array}{l}1.22 \pm \\
0.07(p= \\
0.16)\end{array}$ & $\begin{array}{l}\mathbf{0 . 7 5} \pm \\
\mathbf{0 . 0 5}(p= \\
0.0054)\end{array}$ & $\begin{array}{l}0.83 \pm \\
0.19(p= \\
0.42)\end{array}$ & $\begin{array}{l}0.48 \pm \\
0.16(p= \\
0.013)\end{array}$ \\
\hline TG & $\begin{array}{l}\mathbf{0 . 5 3} \pm \\
\mathbf{0 . 1 9}(p= \\
0.024)\end{array}$ & $\begin{array}{l}\mathbf{0 . 3 6} \pm \\
\mathbf{0 . 0 8}(p= \\
0.044)\end{array}$ & $\begin{array}{l}\mathbf{0 . 3 0} \pm \\
\mathbf{0 . 0 6}(p= \\
0.0008)\end{array}$ & $\begin{array}{l}\mathbf{0 . 3 5} \pm \\
\mathbf{0 . 0 7}(p= \\
0.0012)\end{array}$ & $\begin{array}{l}\mathbf{0 . 4 5} \pm \\
\mathbf{0 . 0 4}(p= \\
0.011)\end{array}$ & $\begin{array}{l}0.64 \pm \\
0.35(p= \\
0.19)\end{array}$ & $\begin{array}{l}0.98 \pm \\
0.08(p= \\
0.83)\end{array}$ & $\begin{array}{l}0 \pm \\
7(p= \\
0)\end{array}$ & $\begin{array}{l}0.61 \pm \\
0.04(p= \\
0.034)\end{array}$ & $\begin{array}{l}\mathbf{0 . 5 4} \pm \\
\mathbf{0 . 0 8}(p= \\
0.013)\end{array}$ \\
\hline A & $\begin{array}{l}\mathbf{0 . 5 2} \pm \\
\mathbf{0 . 2 2}(p= \\
0.00012)\end{array}$ & $\begin{array}{l}\mathbf{0 . 3 6} \pm \\
\mathbf{0 . 0 3}(p= \\
0.008)\end{array}$ & $\begin{array}{l}0.37 \pm \\
0.06(p= \\
0.0009)\end{array}$ & $\begin{array}{l}0.74 \pm \\
0.09(p= \\
0.16)\end{array}$ & $\begin{array}{l}\mathbf{0 . 2 8} \pm \\
\mathbf{0 . 0 5}(p= \\
0.0024)\end{array}$ & $\begin{array}{l}0.28(p= \\
0.12)\end{array}$ & $\begin{array}{l}1.67 \pm \\
0.37(p= \\
0.055)\end{array}$ & $\begin{array}{l}0.87 \pm \\
0.16(p= \\
0.52)\end{array}$ & $\begin{array}{l}0.25 \pm \\
0.04(p= \\
0.002)\end{array}$ & $\begin{array}{l}\mathbf{0 . 8 1} \pm \\
\mathbf{0 . 0 5}(p= \\
0.013)\end{array}$ \\
\hline FGF18 & $\begin{array}{l}\mathbf{0 . 4 5} \pm \\
\mathbf{0 . 2 5}(p= \\
0.012)\end{array}$ & $\begin{array}{l}\mathbf{0 . 3 3} \pm \\
\mathbf{0 . 0 2}(p< \\
0.0001)\end{array}$ & $\begin{array}{l}0.21 \pm \\
0.06(p= \\
0.0002)\end{array}$ & $\begin{array}{l}0.40 \pm \\
0.09(p= \\
0.037)\end{array}$ & $\begin{array}{l}\mathbf{0 . 3 5} \pm \\
\mathbf{0 . 0 6}(p= \\
0.0054)\end{array}$ & $\begin{array}{l}0.66 \pm \\
0.54(p= \\
0.35)\end{array}$ & $\begin{array}{l}1.16 \pm \\
0.09(p= \\
0.20)\end{array}$ & $\begin{array}{l}1.16 \pm \\
0.47(p= \\
0.47)\end{array}$ & $\begin{array}{l}0.67 \pm \\
0.14(p= \\
0.075)\end{array}$ & $\begin{array}{l}\mathbf{0 . 5 5} \pm \\
\mathbf{0 . 0 6}(p= \\
0.0008)\end{array}$ \\
\hline $\mathbf{I}$ & $\begin{array}{l}\mathbf{0 . 3 4} \pm \\
\mathbf{0 . 1 0}(p= \\
0.0018)\end{array}$ & $\begin{array}{l}\mathbf{0 . 0 7} \pm \\
\mathbf{0 . 0 2}(p= \\
0.0071)\end{array}$ & $\begin{array}{l}0.19 \pm \\
0.12(p= \\
0.0005)\end{array}$ & $\begin{array}{l}0.22 \pm \\
0.04(p= \\
0.035)\end{array}$ & $\begin{array}{l}\mathbf{0 . 1 6} \pm \\
\mathbf{0 . 0 1}(p= \\
0.0012)\end{array}$ & $\begin{array}{l}0.87 \pm \\
0.20(p= \\
0.20)\end{array}$ & $\begin{array}{l}1.22 \pm \\
0.23(p= \\
0.22)\end{array}$ & $\begin{array}{l}4 \pm \\
9(p= \\
15)\end{array}$ & $\begin{array}{l}0.53 \pm \\
0.21(p= \\
0.041)\end{array}$ & $\begin{array}{l}\mathbf{0 . 4 5} \pm \\
\mathbf{0 . 0 4}(p= \\
0.0018)\end{array}$ \\
\hline 315 & $\begin{array}{l}\mathbf{0 . 3 6} \pm \\
\mathbf{0 . 1 9}(p= \\
0.0059)\end{array}$ & $\begin{array}{l}\mathbf{0 . 1 3} \pm \\
\mathbf{0 . 0 6}(p= \\
0.0067)\end{array}$ & $\begin{array}{l}\mathbf{0 . 1 6} \pm \\
\mathbf{0 . 0 3}(p= \\
0.0026)\end{array}$ & $\begin{array}{l}0.34 \pm \\
0.09(p= \\
0.0013)\end{array}$ & $\begin{array}{l}\mathbf{0 . 1 6} \pm \\
\mathbf{0 . 0 1}(p= \\
0.00091)\end{array}$ & $\begin{array}{l}0.89 \pm \\
0.15(p= \\
0.38)\end{array}$ & $\begin{array}{l}\mathbf{3 . 6 0} \pm \\
\mathbf{0 . 2 8}(p= \\
0.0004)\end{array}$ & $\begin{array}{l}1 \pm \\
8(p= \\
7)\end{array}$ & $\begin{array}{l}0.44 \pm \\
0.19(p= \\
0.020)\end{array}$ & $\begin{array}{l}\mathbf{0 . 6 4} \pm \\
\mathbf{0 . 1 6}(p= \\
0.025)\end{array}$ \\
\hline 2 & $\begin{array}{l}\mathbf{0 . 6 0} \pm \\
\mathbf{0 . 1 7}(p= \\
0.01)\end{array}$ & $\begin{array}{l}0.24 \pm \\
0.09(p= \\
0.0016)\end{array}$ & $\begin{array}{l}0.34 \pm \\
0.13(p= \\
0.011)\end{array}$ & $\begin{array}{l}0.30 \pm \\
0.01(p< \\
0.0001)\end{array}$ & $\begin{array}{l}\mathbf{0 . 3 1} \pm \\
\mathbf{0 . 0 3}(p= \\
0.011)\end{array}$ & $\begin{array}{l}0.99 \pm \\
0.51(p= \\
0.96)\end{array}$ & $\begin{array}{l}\mathbf{0 . 5 5} \pm \\
\mathbf{0 . 0 9}(p= \\
0.0034)\end{array}$ & $\begin{array}{l}1.24 \pm \\
0.18(p= \\
0.15)\end{array}$ & $\begin{array}{l}0.37 \pm \\
0.06(p= \\
0.015)\end{array}$ & $\begin{array}{l}0.42 \pm \\
0.14(p= \\
0.019)\end{array}$ \\
\hline RAMP3 & $\begin{array}{l}\mathbf{0 . 5 1} \pm \\
\mathbf{0 . 4 1}(p= \\
0.021)\end{array}$ & $\begin{array}{l}0.69 \pm \\
0.40(p= \\
0.27)\end{array}$ & $\begin{array}{l}0.41 \pm \\
0.15(p= \\
0.001)\end{array}$ & $\begin{array}{l}0.33 \pm \\
0.09(p= \\
0.023)\end{array}$ & $\begin{array}{l}\mathbf{0 . 3 0} \pm \\
\mathbf{0 . 0 4}(p= \\
0.0086)\end{array}$ & $\begin{array}{l}0.32 \pm \\
0.24(p= \\
0.013)\end{array}$ & $\begin{array}{l}\mathbf{0 . 5 9} \pm \\
\mathbf{0 . 1 0}(p= \\
0.022)\end{array}$ & $\begin{array}{l}\mathbf{0 . 6 4} \pm \\
\mathbf{0 . 0 9}(p= \\
0.023)\end{array}$ & $\begin{array}{l}0.39 \pm \\
0.06(p= \\
0.015)\end{array}$ & $\begin{array}{l}\mathbf{0 . 3 7} \pm \\
\mathbf{0 . 0 7}(p= \\
0.012)\end{array}$ \\
\hline YPEL-1 & $\begin{array}{l}\mathbf{0 . 4 4} \pm \\
\mathbf{0 . 2 6}(p= \\
0.018)\end{array}$ & $\begin{array}{l}0.83 \pm \\
0.20(p= \\
0.4)\end{array}$ & $\begin{array}{l}0.81 \pm \\
0.04(p= \\
0.17)\end{array}$ & $\begin{array}{l}0.55 \pm \\
0.08(p= \\
0.06)\end{array}$ & $\begin{array}{l}\mathbf{0 . 3 5} \pm \\
\mathbf{0 . 0 9}(p= \\
0.028)\end{array}$ & $\begin{array}{l}0.23 \pm \\
0.19(p= \\
0.010)\end{array}$ & $\begin{array}{l}0.88 \pm \\
0.32(p= \\
0.61)\end{array}$ & $\begin{array}{l}0.62 \pm \\
0.19(p= \\
0.25)\end{array}$ & $\begin{array}{l}0.21 \pm \\
0.10(p= \\
0.015)\end{array}$ & $\begin{array}{l}0.63 \pm \\
0.13(p= \\
0.082)\end{array}$ \\
\hline
\end{tabular}

*expression relative to control condition as measured by Q-RT-PCR after 2 days of incubation. Statistically significant changes are marked in bold. Genes are ordered by the strength of their response to siIGFBP5. RAMP3 and YPEL-1 are listed separately, as their expression is not significantly changed in response to MSCs in 3D spheroid cultures.

${ }^{(\#)}$ condition as used for cRNA microarray analysis. TW $=$ transwell.

KLHL4 = kelch-like 4, SEPP1 = selenoprotein P. plasma 1, TMEM26 = transmembrane protein 26, TGFBR3 = transforming growth factor $\beta$ receptor III, RAB30 = RAB30, member RAS oncogene family, FGF18 = fibroblast growth factor 1 , KLK11 $=$ kallikrein-related peptidase 1, UGT2B15 = UDP glucuronosyl transferase 2 family polypeptide B15, KIF12 = kinesin family member 12, RAMP3 = receptor $(\mathrm{G}$ protein-coupled $)$ activity modifying protein 3, YPEL-1 = yippee-like 1 

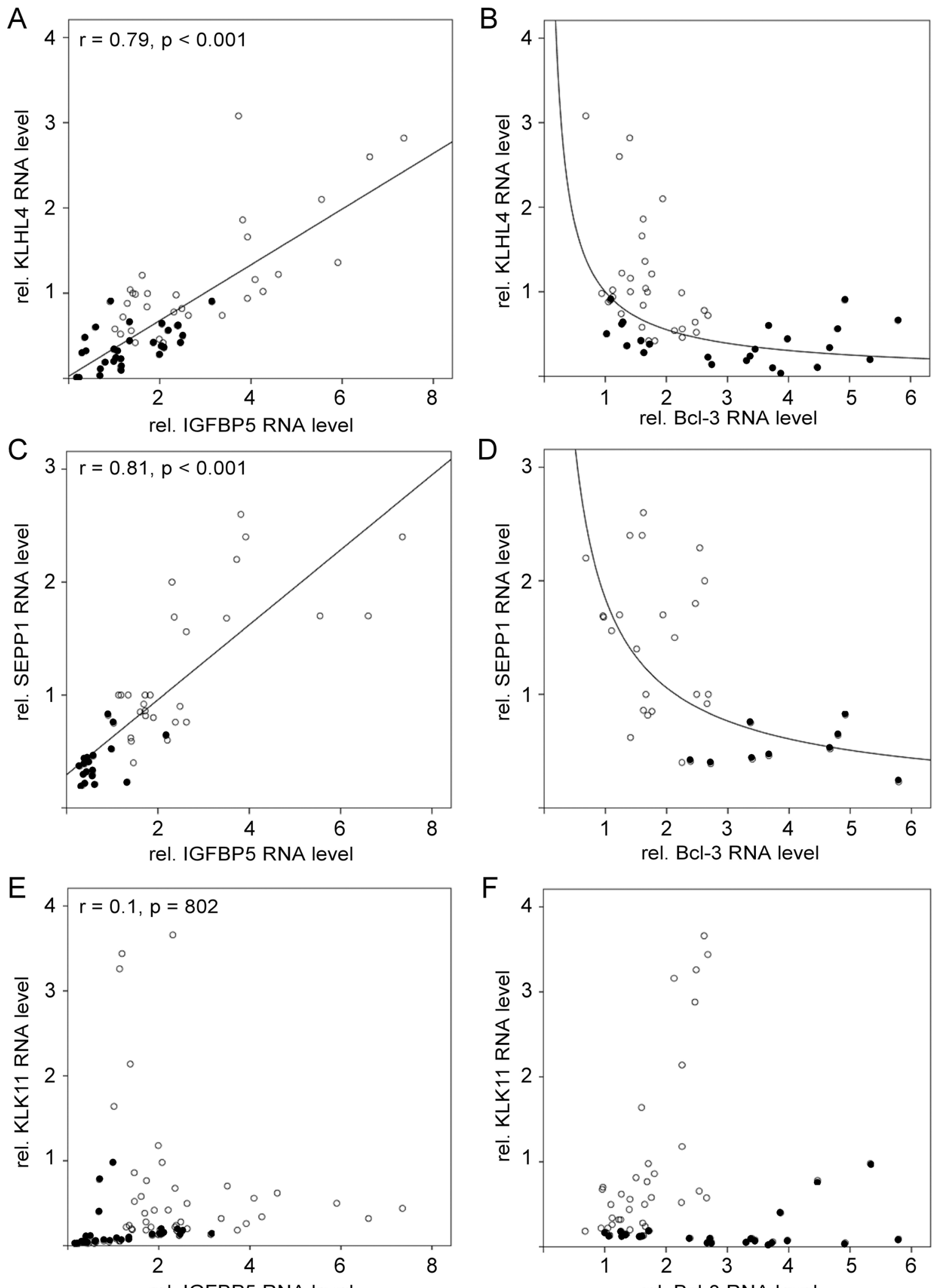

rel. IGFBP5 RNA level

Figure 6: KLHL4 and SEPP1 mRNA levels change along with the IGFBP5 mRNA level in a linear fashion. A-F. RTPCR analyses of RNA isolated from MCF-7 cells either exposed to CAF-CM (•) or left untreated (O). Levels of KLHL4-, SEPP1- and KLK11-specific mRNAs were either compared with the mRNA level of IGFBP5 (A, C, E) or with the mRNA level of Bcl-3 (B, D, F). 
A

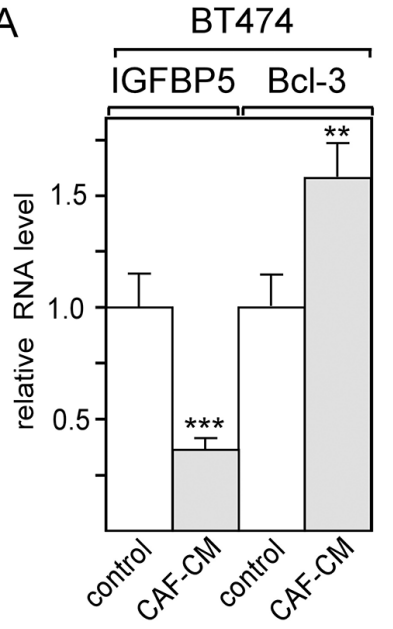

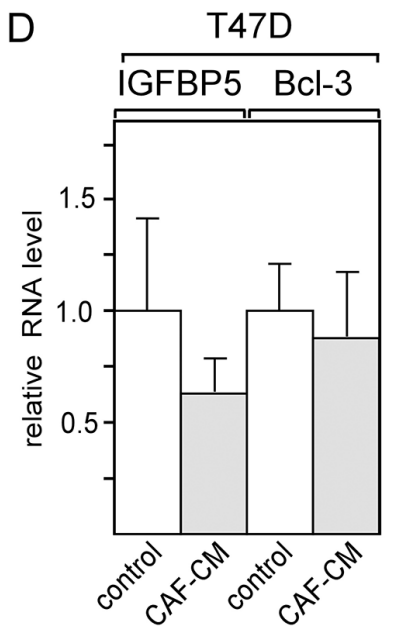

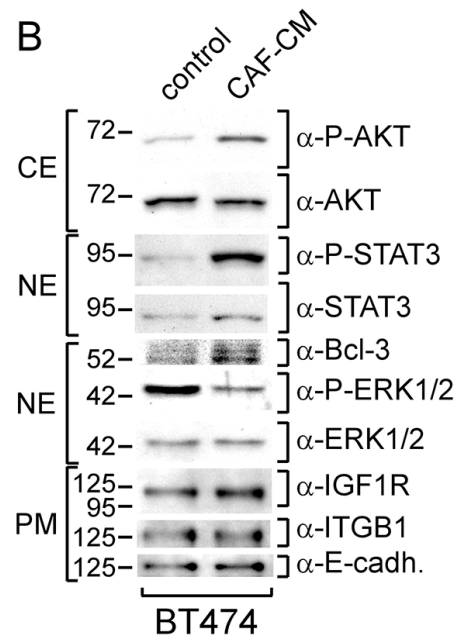

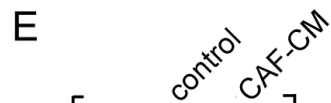

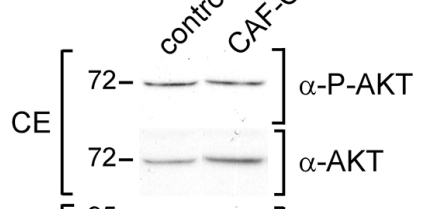

$\left[\begin{array}{l}95- \\ 72- \\ 95-\end{array}\right] \alpha-P-S T A T 3$

$\mathrm{F}$
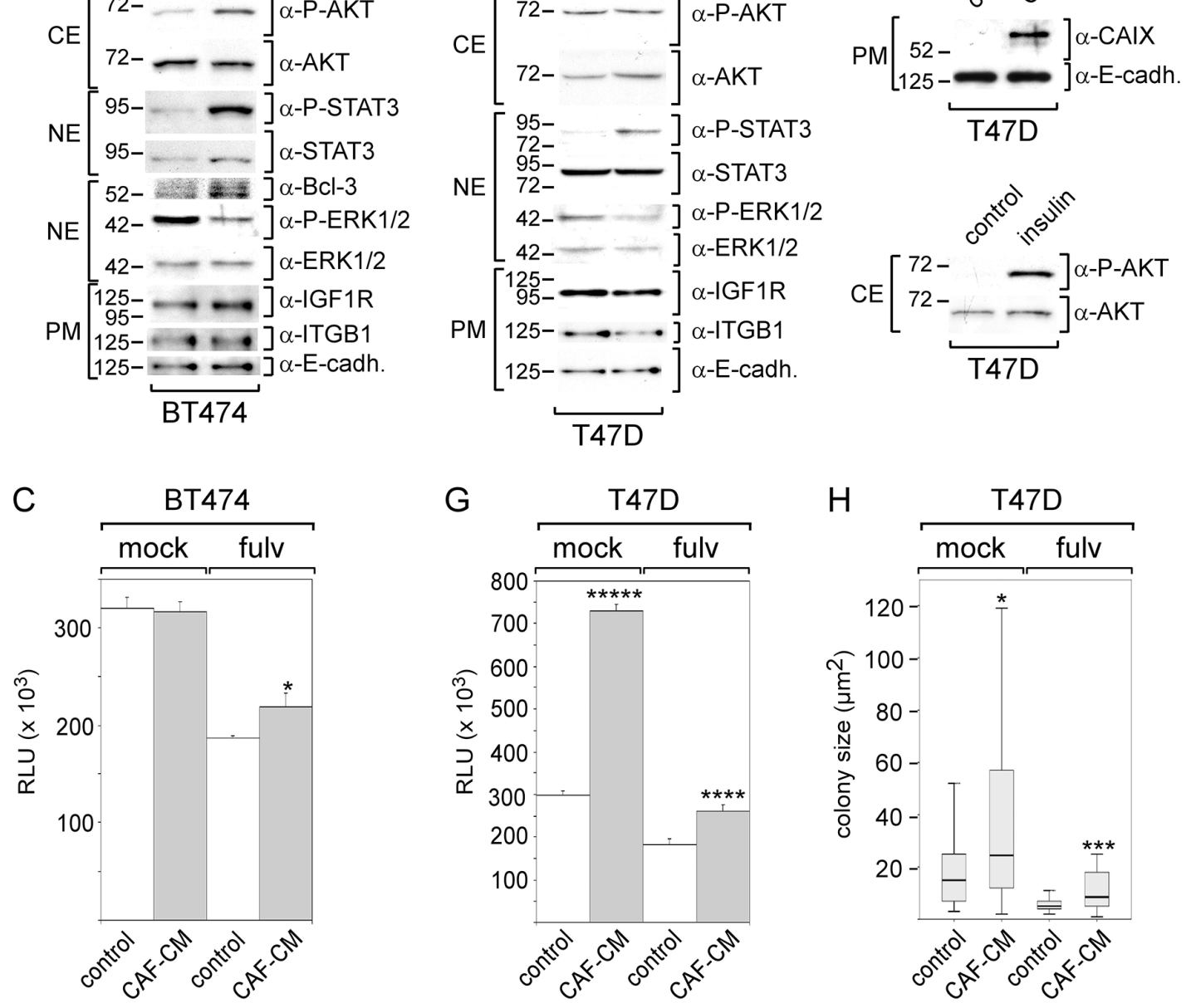

Figure 7: BT474, but not T47D cells respond to CAF-CM by changing IGFBP5 and Bcl-3 levels and by increasing growth activity in the presence of fulvestrant. A-D. After BT474 cells (A, B) or T47D cells (D, E.) were treated with CAF-CM or left untreated for three days, RNA or proteins were isolated and analyzed for IGFBP5 and Bcl-3 RNA levels (A, D) or levels of certain proteins as indicated $(\mathrm{B}, \mathrm{E})$, respectively. To check for equal loading of plasma membrane proteins, blots were reprobed with an E-cadherin -specific antibody ( $\alpha$-E-cadh.). F. T47D cells were also tested for AKT phosphorylation and CAIX expression after 3-day-treatment with insulin or $\mathrm{CoCl}_{2}$, respectively. (C, G, H.) Effect of CAF-CM on BT474 and T47D cell growth in the presence or absence of fulvestrant as measured either by an ATP based assay $(\mathrm{C}, \mathrm{G})$ or by measuring the sizes of single colonies $(\mathrm{H})$. In $(\mathrm{A}, \mathrm{C}, \mathrm{D}, \mathrm{G})$, each bar represents the mean value \pm S.D. of at least three independent experiments, in $(\mathrm{H})$, the data of a representative experiment are shown. Statistical analysis was either performed by using the student's $t$-test (A, C, D, G) or the Wilcoxon test $(\mathrm{H})$. 
T47D cells, we treated these cells with insulin and $\mathrm{CoCl}_{2}$. Insulin and $\mathrm{CoCl}_{2}$ were able to raise the P-AKT level or CAIX level, respectively, (Figure 7F) demonstrating that the failure of CAF-CM to induce insulin- and $\mathrm{CoCl}_{2}$-like effects in T47D cells was not due to unresponsiveness of the PI3K/AKT and HIF $1 \alpha /$ CAIX pathways. In ATP- and colony growth assays, CAF-CM showed a promoting effect on T47D cell growth irrespective of whether fulvestrant was present or not (Figure 7G, 7H).

The data obtained with T47D cells suggest that the responses of ER $\alpha$-positive breast cancer cells to stromal cells can differ.

\section{The expression of Bcl-3 is associated with an unfavorable outcome of endocrinally treated breast cancer patients with $\mathbf{E R} \alpha /$ PR-positive tumors}

We next sought to analyze whether Bcl-3 is associated with the outcome of breast cancer patients that suffered from ER $\alpha / P R$-positive tumors and received endocrine treatment. For this reason, we performed an in-silico analysis by using the Kaplan-Meier-Plotter available under http://kmplot.com/analysis/index. php $\mathrm{p}=$ service \&default $=$ true which is based on data published by Gyorffy et al. [43]. The selected criteria $\left(\mathrm{ER} \alpha^{+} / \mathrm{PR}^{+} /\right.$received endocrine treatment) were met by a cohort of 229 patients. The analysis for this cohort revealed that higher Bcl-3 mRNA levels were significantly associated with a more unfavorable relapse-free survival (Figure 8A). We also run the analysis for KLHL4 and SEPP1, whose expression could be increased by siBcl-3 and showed an inverse correlation to that of Bcl-3. For these two genes, higher mRNA levels correlated with a better relapse-free survival (Figure 8B, 8C). While the data for KLHL4 slightly missed the significance level ( $p=0.051$ ) (Figure 8B), those for SEPP1 were highly significant (Figure 8C). Collectively, these data are consistent with the notion that Bcl-3 is involved in endocrine resistance and that KLHL4 and SEPP1 are negatively regulated by $\mathrm{Bcl}-3$. The data might also suggest that $\mathrm{Bcl}-3$ mediates endocrine resistance at least partially by downregulating KLHL4 and SEPP1.

\section{DISCUSSION}

The data presented here show that MSCs and CAFs affect ER $\alpha$-positive breast cancer cells in a similar way. They promote cellular growth in the presence of the anti-estrogen fulvestrant and change the activities of the same signaling pathways and the expression of the same proteins. Most of the changes in signaling pathway activities and protein expression could be recapitulated by combined treatment with insulin and $\mathrm{CoCl}_{2}$. Only stromal cell-induced changes in IGF1R and Bcl-3 expression could not be mimicked by a combination of these agents. We present evidence that stromal cells induce all of these changes by downregulating IGFBP5 expression. Downregulation of IGFBP5 also contributed to the activation of STAT3. It seems therefore that, by downregulating IGFBP5, MSCs and CAFs coordinately induce a wide range of changes in breast cancer cells.

Since some changes as induced by IGFBP5 downregulation could be mimicked by insulin, some by $\mathrm{CoCl}_{2}$ and others neither by insulin nor $\mathrm{CoCl}_{2}$, it is likely that IGFBP5 fulfills several different functions in breast cancer cells. Besides its classical function as a regulator of IGF-dependent IGF1R activation [44], IGF1Rindependent actions of IGFBP5 have been described [19]. E.g., it has been shown that, by binding to integrin $\alpha 2$ / $\beta 1$, IGFBP5 is able to regulate cell adhesion, migration and survival of MCF-7 cells [20]. This activity did not require the $\mathrm{N}$-terminal domain, which is responsible for its IGF1R-depending action, but the C-terminal domain, which interacts with heparin. The notion that the N- and C-terminal domains of IGFBP5 have different functions is also supported by a study that showed that the N-terminal domain blocks proliferation of osteosarcoma cells and induces apoptosis, whereas the C-terminal domain inhibits migration and invasion [45]. In addition, the C-terminal domain contains a nuclear localization sequence allowing IGFBP5 to fulfill functions in the nucleus [46]. IGF1Rindependent functions of IGFBP5 have also been found invivo studies [47] just further substantiating the hypothesis that at least two independent activities of IGFBP5 exist.

Downregulation of IGFBP5 by siIGFBP5 resulted in increased cellular growth both in the presence and absence of fulvestrant. The effect of siIGFBP5 on cell growth in the absence of fulvestrant could be mediated by its insulinlike effect on P-AKT, since insulin was able to foster cell growth in absence, but not in the presence of fulvestrant. The effect of siIGFBP5 on cell growth in the presence of fulvestrant is likely mediated by upregulation of Bcl-3 expression, since siBcl-3 specifically attenuated cellular growth in the presence of fulvestrant, while showing no effect on growth in its absence. Hence, Bcl-3 may protect ER $\alpha$-positive breast cancer cells, such as MCF-7 cells, against fulvestrant. In line with this hypothesis, a previous study on MCF-7 cells grown in ovariectomized mice showed that estrogen deficiency was linked to higher Bcl-3 expression [28]. In this study, along with the higher expression of Bcl-3, a higher DNA-binding activity of NF $\mathrm{B}$ was observed. By binding to p50/p50 and p52/ p52 NFкB homodimers, Bcl-3 is thought to increase NFאB activity [27]. Thus, by upregulating Bcl-3 levels in ER $\alpha$-positive breast cancer cells, MSCs and CAFs may pave the way towards an NFkB-dependent growth under conditions where $\mathrm{ER} \alpha$ is not functional. Interestingly, $\mathrm{NF} \kappa \mathrm{B}$ activation does not only protect against loss of $\mathrm{ER} \alpha$ function, but also promotes growth of Her2-positive breast cancer cells in the presence of a Her2 inhibitor [48] suggesting that NFKB activation is a general option for 


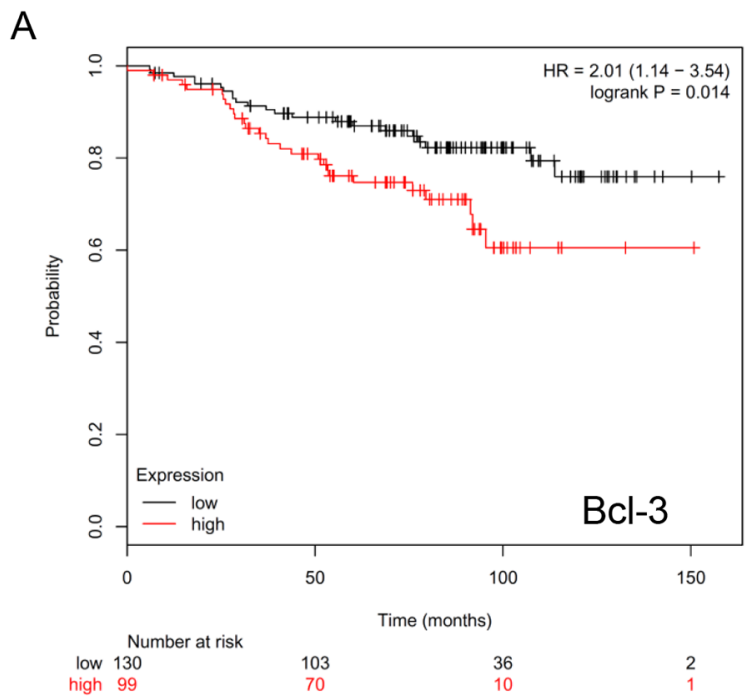

B
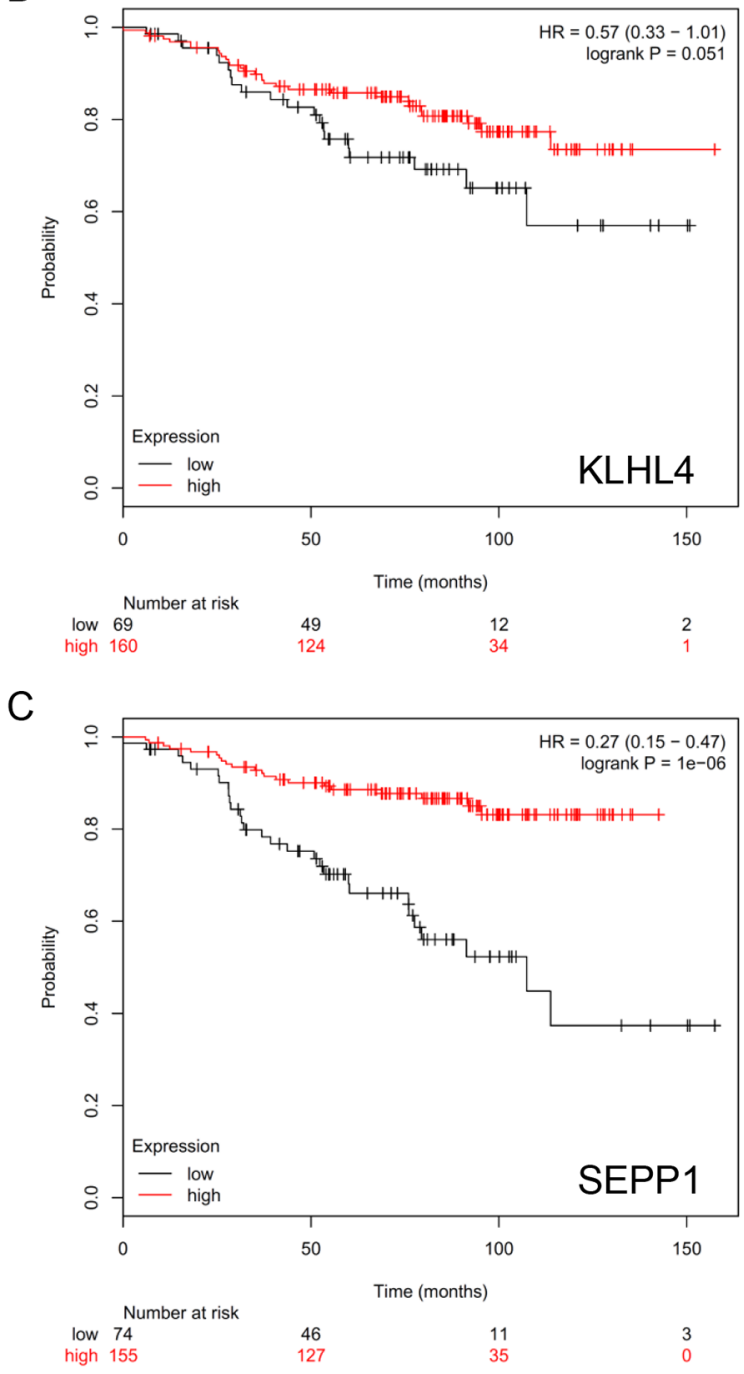

Figure 8: Higher Bcl-3 expression is associated with an unfavorable prognosis of endocrinally treated breast cancer patients with $\mathbf{E R} \boldsymbol{\alpha}+/ \mathbf{P R}+-$ tumors. In silico-Kaplan-Meier-Plotter analysis of 229 endocrinally treated breast cancer patients with $\mathrm{ER}^{+} / \mathrm{PR}^{+}$-tumors for an association of outcome (relapse-free survival) with Bcl-3 A. KLHL4 B. or SEPP1 C. expression by choosing best cut-off. 
breast cancer cells to survive under conditions where the major growth-permitting pathway is blocked. In line with this notion, ER $\alpha$-negative breast cancer cells are found to be more dependent on NFKB activity for proliferation than ER $\alpha$-positive cells [49].

We could show that stromal cell-induced downregulation of IGFBP5 expression and concomitant upregulation of Bcl-3, IGF1R and P-AKT levels is not only seen with MCF-7 cells, but also with BT474 cells. This suggests that the observed changes as inflicted by stromal cells are not limited to a specific cell line, but of greater importance. On the other hand, the failure of T47D cells to react this way upon exposure to stromal cells indicates that breast cancer cells do not necessarily respond to stromal cells by inducing changes in IGFBP5 and Bcl-3 expression. T47D cells expressed Bcl-3 protein at non-detectable level as judged by Western blot analysis. Hence, it is unlikely that Bcl-3 is involved in fulvestrant resistance developed by T47D cells. In agreement with this notion, recent data showed that T47D cells activate Aurora kinase B to gain fulvestrant resistance [50].

How stromal cells downregulate IGFBP5 expression in breast cancer cells has still to be determined. IGFBP5 expression has been reported to be positively regulated by STAT3 in fibroblasts [51]. However, we did not find an effect of siSTAT3 on the IGFBP5 level in MCF-7 cells (Figure 4A). Nor did siSTAT3 prevent the stromal cell-induced effects on signaling pathways and protein expression (Figure 2E). Hence, interleukin-6, the major stromal-cell secreted stimulator of STAT3 activity $[52,53]$, is unlikely to be responsible for IGFBP5 downregulation and its consequences. We also tested SDF-1 (stromal cell derived factor-1) and other cytokines, known to be secreted by stromal cells, for their ability to downregulate IGFBP5, but so far we did not see any effect. MSCs and CAFs also secret high amounts of PAI1 (plasminogen activator inhibitor-1) (data not shown). This protease inhibitor has several functions, including a critical role in migration [54], which links this protein to cancer progression [55]. To analyze its importance for the stromal cell-induced effects, we eliminated PAI1 from CAF-CM by transfecting CAFs with a PAI-1specific siRNA, but did not find any evidence that this treatment changes the ability of CAF-CM to induce IGFBP5 downregulation in MCF-7 cells (data not shown). Besides secreted proteins, microvesicles (exosomes and shedding vesicles) as released by MSCs and CAFs [56, 57], might be responsible for the induction of IGFBP5 downregulation. In terms of shedding vesicles, we could confirm that they are released by MSCs (data not shown). We are currently studying their potential role in stromal cell-induced IGFBP5 downregulation.

By a comparative gene expression analysis of MCF-7 cells grown alone or in the presence of MSCs we identified a number of genes whose expression is downregulated in response to MSCs and CAFs. The levels of approximately half of these genes were also decreased by siIGFBP5. Of these genes, KLHL4 and SEPP1 were upregulated by $\mathrm{siBcl} 3$. The expression of these two genes changed along with the level of IGFBP5 in a linear fashion and inversely along with that of $\mathrm{Bcl} 3$. This suggests that KLHL4 and SEPP1 can be regulated through the IGFBP5/Bcl-3 axis. Interestingly, treatment of MCF-7 cells with TNF $\alpha$, which stimulates NFאB activity, was found to downregulate SEPP1 [58] suggesting that SEPP1 is an NFאB/Bcl-3 target at least in MCF-7 cells. However, since downregulation of SEPP1 expression could also be induced by insulin and $\mathrm{CoCl}_{2}, \mathrm{NF \kappa B} / \mathrm{Bcl}-$ 3 may act in concert with HIF $1 \alpha$ and the PI3K/AKT pathway, all activated by stromal cell-induced IGFBP5 downregulation. One way by which the PI3K/AKT pathway could downregulate SEPP1 expression is by inhibiting the activity of the forkhead box transcription factor FoxO1A [59-61], a tumor suppressor protein shown to activate SEPP1 transcription in hepatoma cells [59]. Interestingly, in in-silico survival analysis, we found a correlation of higher Bcl-3 expression and lower KLHL4 and SEPP1 expression with unfavorable outcome of endocrinally treated breast cancer patients that suffered from a $\mathrm{ER} \alpha^{+} / \mathrm{PR}^{+}$-tumor suggesting that not only $\mathrm{Bcl}-3$ is linked to endocrine resistance, but also its target genes KLHL4 and SEPP1.

In conclusion, our results suggest that MSCs and CAFs are able to trigger downregulation of IGFBP5 expression in ER $\alpha$-positive breast cancer cells, such as MCF-7 cells, and, as a consequence, induce a number of changes in signaling pathway activities and gene expression (summarized in Figure 9). One of these changes, the upregulation of $\mathrm{Bcl}-3$ expression, is at least partly responsible for the promoting effect of MSCs and CAFs on the cellular growth in the presence of fulvestrant. Our data also show that, even within the subgroup of ER $\alpha$-positive breast cancer, cancer cells may or may not respond to MSCs and CAFs by downregulating IGFBP5 expression indicating that $\mathrm{ER} \alpha$-positive breast cancers are a heterogeneous group also in respect to their interactions with stromal cells.

Since Bcl-3 expression could be linked to unfavorable prognosis of breast cancer patients that received endocrine treatment, Bcl-3 may be a suitable biomarker for predicting endocrine therapy response of patients with ER $\alpha$-/PR-positive breast cancers.

\section{MATERIALS AND METHODS}

\section{Cell culture}

MCF-7, BT474 and T47D breast cancer cells, whose identities were confirmed by authentication (LGC standards, Wesel, Germany or Genolytic, Leipzig, Germany), and immortalized 19TT breast CAFs $[62,63]$ were maintained in RPMI medium supplemented with $10 \%$ fetal calf serum 


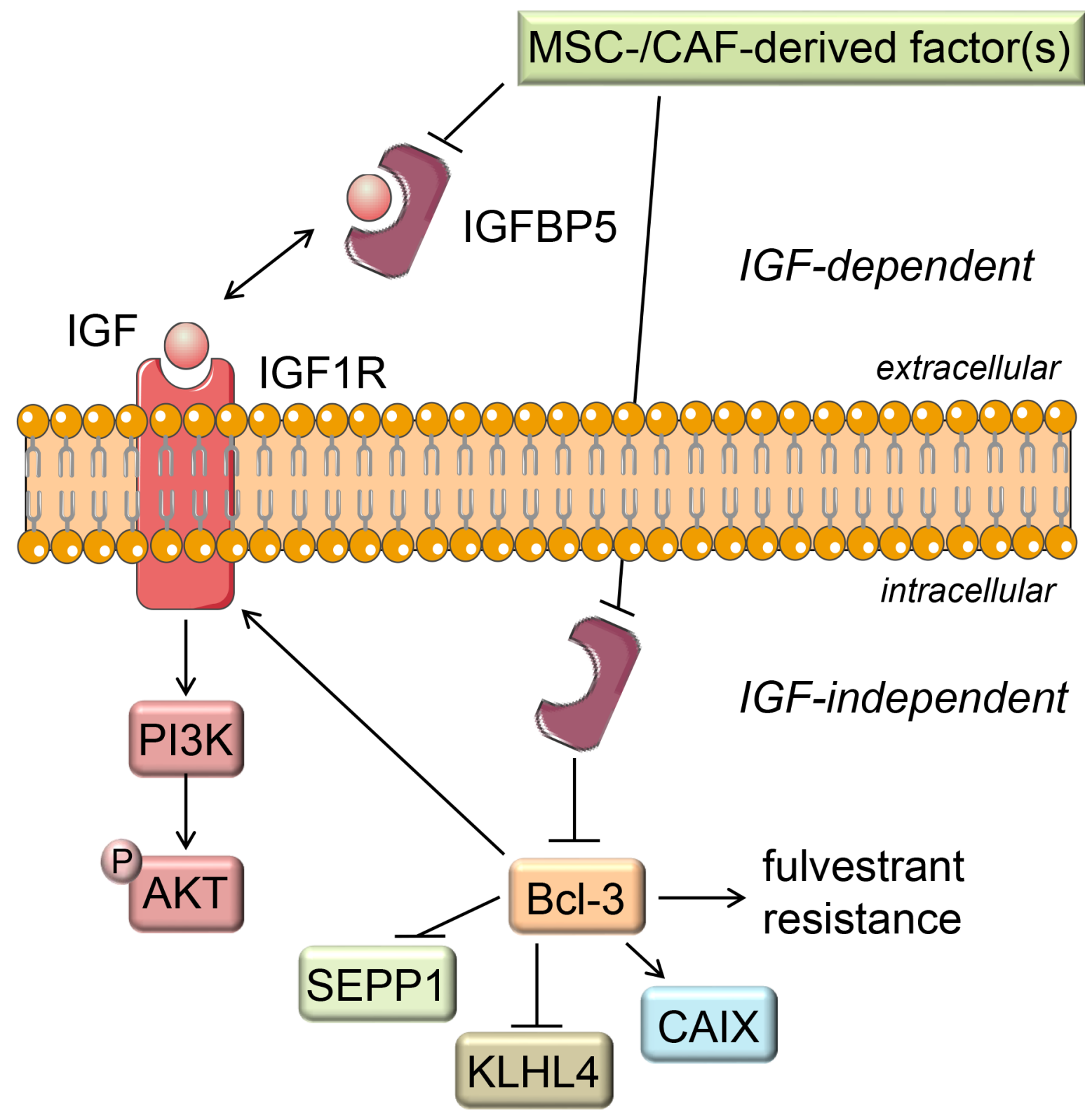

Figure 9: Proposed mechanism of stromal cell induced fulvestrant resistance. Factor(s) secreted by MSCs and CAFs lead to a decline in the IGFBP5 expression. The reduced IGFBP5 level results in the release of IGFs from the IGF/IGFBP5 complex allowing IGF to activate IGF1R, thereby activating the PI3K/AKT signaling pathway. Besides blocking IGF activity by this IGF-dependent function, IGFBP5 also shows IGF-independent actions (e.g. as an intracellular protein). Through this IGF-independent action IGFBP5 likely keeps Bcl-3 expression down. Consequently, when stromal cells downregulate IGFBP5 expression the Bcl-3 expression raises. This leads to fulvestrant resistance and to changes in the expression of the Bcl-3 target genes IGF1R, KLHL4 and SEPP1.

(FCS, Pan Biotech) in the absence of antibiotics. Human MSCs were kindly provided by J. Lützkendorf and L. Müller. MSCs were isolated from human bone marrow and propagated as described [35]. Breast cancer cell lines and stromal cells were maintained in the same batch of serum. To obtain conditioned medium (CM) from CAFs (CAFCM), cells were kept at $100 \%$ confluency for three days. For MSC-CM, MSCs were kept at $\sim 50 \%$ confluency for three days (to prevent differentiation). To remove floating cells and debris, CMs were centrifuged at $3000 \mathrm{rpm}$ in a Multifuge 3 (Heraeus) for 10 minutes. Unless stated otherwise, for treatment with stromal cell CM, MSC- or CAF-CM was mixed with growth medium $1+4$, referred as $20 \%$ MSC-CM or 20\% CAF-CM, respectively. Cells were incubated with $\mathrm{CM}$ for 3 days. Co-culture experiments were performed by mixing MCF-7 cells with MSCs in a ratio of 10:1 or 50:1. In transwell experiments, MSCs were separated from MCF-7 cells by a $0.4 \mu \mathrm{m}$ pore membrane (Greiner) with the MCF-7 cells grown on the bottom of the well of a 6-well-plate and the MSCs attached to the upper side of the membrane. Spheroid assays were performed as described [35]. Based on data reported by Kirkegaard 
et al. [64] cell were incubated with fulvestrant at a final concentrations of $100 \mathrm{nM}$. Insulin, PQ401 and $\mathrm{CoCl}_{2}$ were added to cells at a final concentration of $8 \mu \mathrm{g} / \mathrm{ml}(\sim 90 \mu \mathrm{IU} /$ $\mathrm{ml}$, as determined by insulin ELISA, Hölzel Diagnostika), $10 \mu \mathrm{M}$ and $100 \mu \mathrm{M}$, respectively.

For spheroid formation in 3D suspension cultures, cells were incubated on a layer of $2 \%$ Seakem GTG agarose (dissolved in PBS) in 96-well plates at a density of $5 \times 10^{3}$ cells/well for 3-4 days in the presence of fulvestrant and/or CAF-CM or in the absence of both agents. To measure the spheroid size, a picture was taken by an AxioCam MRc 5 camera and the area displayed on this picture measured by AxioVision R 4.5 software as described previously [65].

\section{Antibodies and reagents}

For Western blot analysis, the following antibodies were used (working dilutions are given in brackets). Rabbit polyclonal antibodies: anti-P(S473)-AKT (1:2000, D9E, Cell Signaling), anti-Bcl-3 (1:1000, C-14, Santa Cruz), anti-P(Thr202, Tyr204)-ERK1/2 and anti-ERK1/2 (both 1:2000, Cell Signaling), anti-ER $\alpha$ (1:2000, Santa Cruz, HC-20), anti-IGF1R $\beta$ (1:2000, Cell Signaling), anti-P(Tyr705)-STAT3 (1:1000, D3A7, Cell Signaling) and anti-STAT3 (1:1000, 79D7, Cell Signaling); rabbit monoclonal antibodies: anti-integrin $\beta 1$ (1:2000, EPR1040Y, Abcam), anti-GAPDH (1:5000, Ambion) and Ki67 (1: 2000, Epitomics, clone EPR3610); mouse monoclonal antibodies: anti-(pan)AKT (1:1000, 40D4, Cell Signaling), anti-E-cadherin (1:5000, BD Transduction Lab.) and anti-HIF1 $\alpha$ (1:1000, BD Transduction Lab.). Anti-CAIX was kindly provided by S. Pastorekova. Secondary antibody conjugates (anti-rabbit/anti-mouse horse radish peroxidase, 1:2000) were purchased from Cell Signaling.

Fulvestrant (LKT Laboratories) was purchased from Biomol (Hamburg/Germany), PQ404 from Calbiochem and recombinant human insulin was from Sigma-Aldrich.

\section{RNA interference}

Small interference (si)RNAs were purchased from Eurofins MWG. Transfection was performed by electroporation as described [66]. Briefly, cells were trypsinized, washed once in RPMI medium, electroporated by using a Bio-Rad GenePulserX-Cell at $250 \mathrm{~V}$ and $800 \mu \mathrm{F}$ and kept on ice for $30 \mathrm{~min}$. Cells were then transferred to a 6 or $10 \mathrm{~cm}(\square)$ culture dish and incubated for two days to allow the siRNA to downregulate the expression of its target. The effect of the siRNA was confirmed by Western blot and/or Q-RT-PCR analysis. The following siRNAs (sense-strand) were used: siBcl3 (5'-UGG UCU UCU CUC CGC AUC A-3'), siLuc (5'-CUU ACG CUG AGU ACU UCG A-3'), silGFBP5 (5'-GCA GAU CUG UGA AUA UGA A-3') and siSTAT3 (5'-GAA UCA CGC CUU CUA CAG A-3').

\section{Growth assays}

To determine cell growth of individual clones, cells were trypsinized, counted and seeded on a $10 \mathrm{~cm}$ $(\square)$ petri dish $\left(3 \times 10^{4}\right.$ cells per dish) in $10 \mathrm{ml}$ growth medium. Cells were then incubated with MSC-CM, CAF-CM or insulin and/or fulvestrant or left untreated for five days. Cell growth of individual clones were determined by measuring the size of each clone by using an AxioCAM MRc5 camera and the AxioVision R 4.5 imaging software (Zeiss). Single cells were not counted. For each condition, at least fifty individual clones were randomly chosen and measured. In RNA interference experiments, cells were transfected with siRNA and incubated for two days before the clonogenic assay was started.

To examine cell growth activity at higher cell density an ATP-based assay (Vialight Plus Kit, Lonza) was used. Cells were seeded at a density of $1 \times 10^{4}$ or 3 $\times 10^{4}$ per well of a 24-well plate and incubated for 5 to 7 days in the presence of fulvestrant and/or CAF-CM or in the absence of both. After removal of the growth medium, cells were washed once with PBS and lysed by adding a mixture of $100 \mu \mathrm{l}$ PBS and $50 \mu 1$ lysis buffer. Cell lysates were cleared by microfugation at $4000 \mathrm{rpm}$ for $5 \mathrm{~min}$. After $75 \mu \mathrm{l}$ of the cleared lysate was mixed with $50 \mu \mathrm{l}$ luciferase stock solution, the mixture was incubated for $2 \mathrm{~min}$ at RT and luciferase activity measured in a Sirius luminometer (Berthold).

\section{Quantitative RT-PCR}

RNA isolation, cDNA synthesis and quantitative (Q) PCR were carried out as described [66], except that the RNA isolation kit was from Roche and the dNTP mix was from Qiagen. Briefly, cDNA synthesis was done by using Superscript II (Invitrogen) by starting from $1 \mu \mathrm{g}$ total RNA. For Q-PCR, ABsolute QPCR SYBR Green Fluorescein Mix (Thermo Fisher Scientific Biosciences) was used. PCRs were run in a BioRAD iCycler. Results were analyzed by iQ5 Optical System software version 2.1. Relative RNA levels of genes were calculated by the comparative $C t\left(2^{-\Delta \Delta C t}\right)$ method by using GAPDH and HPRT as reference genes for normalization. The primers used for Q-PCR are listed in Supplementary Table S1.

\section{cRNA microarray analysis}

In two independent experiments, $5 \times 10^{5} \mathrm{MCF}-7$ cells were seeded into the well of a 6 -well plate alone or together with $1 \times 10^{4} \mathrm{MSCs}$ and grown for two days before total RNA was isolated. After the RNA was qualitychecked by an Agilent 2100 Bioanalyzer, gene expression analyses were performed by Miltenyi Biotec by using Agilent Whole Human Genome Oligo Microarrays $8 \times 60 \mathrm{~K}$. Briefly, cRNAs were generated from $100 \mathrm{ng}$ 
of each RNA sample by the Agilent Low Input Quick AMP labeling kit (Agilent Technologies). RNAs from control samples (MCF-7 alone) were labeled with $\mathrm{Cy} 3$, those from MCF-7/MSC co-culture samples with Cy5. Of the corresponding Cy3- and Cy5-labeled fragmented cRNAs, $300 \mathrm{ng}$ each were combined and hybridized o/n to the oligo microarray by following the instructions of the manufacturer (Agilent Technologies). Imaging and data analysis was carried out by using Agilent Feature Extraction Software.

\section{Protein extraction and western blot analysis}

Protein extractions from the membraneous, cytosolic and nuclear fractions and Western blot analysis were carried out as described [66]. Briefly, after having been scraped off the plate, cells were centrifuged and resuspended in $400 \mu \mathrm{l}$ buffer A (10 mM HEPES ( $\mathrm{pH}$ 7.9), $10 \mathrm{mM} \mathrm{KCl}, 0.1 \mathrm{mM}$ EDTA, $0.1 \mathrm{mM}$ EGTA) and passed through a 20 -gauge needle. Stepwise centrifugation at 3000,6500 and $13000 \mathrm{rpm}$ in a microfuge was used to obtain cytosolic, nuclear and membraneous protein fractions. For nuclear or membraneous protein extraction, the pellet was extracted in buffer $\mathrm{C}$ (20 mM HEPES (pH 7.9), $400 \mathrm{mM} \mathrm{NaCl}, 1 \mathrm{mM}$ EDTA, 1 mM EGTA, $1 \mathrm{mM}$ DTT) or buffer D (5 mM HEPES (pH 7.9), $0.5 \mathrm{mM}$ K-EDTA (pH 7.2), 1 mM DTT), respectively. For HIF $1 \alpha$ detection, whole cell extracts (WCE) were prepared as described [67]. Briefly, depending on cell density, cell layers were incubated with 100-300 $\mu$ l ice-cold RIPA lysis buffer (50 mM Tris $\mathrm{HCl}(\mathrm{pH} 7.4), 200 \mathrm{mM} \mathrm{NaCl}$, $1 \mathrm{mM}$ EDTA, $1 \mathrm{mM}$ EGTA, 1\% TritonX-100, 0.25\% deoxycholate) containing a protease inhibitor cocktail (1:100) (Sigma-Aldrich, P8340) for 20 min and scraped off from the plate. Lysates were cleared by microfugation at full speed for $10 \mathrm{~min}$.

Ten $\mu \mathrm{g}$ protein of each sample was separated on a $10 \%$ SDS-polyacrylamide gel and transferred to a PVDF membrane (Millipore). After blocking the membrane in 2\% skim milk (Applichem) dissolved in washing buffer (10 mM Tris/HCl (pH 7.5), $100 \mathrm{mM} \mathrm{NaCl}, 1$ mM EDTA), it was sequentially incubated with the primary antibody and the secondary antibody in washing buffer containing $0.2 \%$ skim milk. Peroxidase activity was visualized by chemoluminescence using ECLPlus and Hyperfilm ECL (GE Healthcare).

\section{Statistical analyses}

Data obtained from colony growth assays were analyzed by Wilcoxon matched pair test. For other two group comparisons, two sample $t$-test or paired $t$-test were used depending on whether the data were dependent or independent. A $p$ value of $p<0.05$ was considered to be statistically significant. For all graphs, $* p<0.05, * * p<$ $0.01, * * * p<0.001, * * * * p<0.0005, * * * * * p<0.0001$.

\section{ACKNOWLEDGMENTS AND FUNDING}

We thank Dr. J. Lützkendorf and Dr. L. Müller for kindly providing us with human MSCs and Dr. S. Pastorekova for anti-CAIX. This work was supported by the Deutsche Krebshilfe, Grant No. 109271 and by the Land Sachsen-Anhalt (Graduiertenförderung).

\section{CONFLICTS OF INTEREST}

The authors declare that there are no conflicts of interests.

\section{REFERENCES}

1. Toriola AT, Colditz GA. Trends in breast cancer incidence and mortality in the United States: implications for prevention. Breast Cancer Res Treat. 2013; 138:665-673.

2. Prat A, Perou CM. Deconstructing the molecular portraits of breast cancer. Mol Oncol. 2011; 5:5-23.

3. Davies C, Godwin J, Gray R, Clarke M, Cutter D, Darby S, McGale P, Pan HC, Taylor C, Wang YC, Dowsett M, Ingle J, Peto R. Relevance of breast cancer hormone receptors and other factors to the efficacy of adjuvant tamoxifen: patient-level meta-analysis of randomised trials. Lancet. 2011; 378:771-784.

4. Musgrove EA, Sutherland RL. Biological determinants of endocrine resistance in breast cancer. Nat Rev Cancer. 2009; 9:631-643.

5. Ma CX, Reinert T, Chmielewska I, Ellis MJ. Mechanisms of aromatase inhibitor resistance. Nat Rev Cancer. 2015; 15:261-275.

6. Junttila MR, de Sauvage FJ. Influence of tumour microenvironment heterogeneity on therapeutic response. Nature. 2013 ; 501:346-354.

7. Correia AL, Bissell MJ. The tumor microenvironment is a dominant force in multidrug resistance. Drug Resist Updat. 2012; 15:39-49.

8. Dittmer J, Leyh B. The impact of tumor stroma on drug response in breast cancer. Semin Cancer Biol. 2015; 31:3-15.

9. Paraiso KH, Smalley KS. Fibroblast-mediated drug resistance in cancer. Biochem Pharmacol. 2013; 85:1033-1041.

10. Mao Y, Keller ET, Garfield DH, Shen K, Wang J. Stromal cells in tumor microenvironment and breast cancer. Cancer Metastasis Rev. 2013; 32:303-315.

11. Cuiffo BG, Karnoub AE. Mesenchymal stem cells in tumor development: emerging roles and concepts. Cell Adh Migr. 2012; 6:220-230.

12. Dittmer J, Oerlecke I, Leyh B. Involvement of Mesenchymal Stem Cells in Breast Cancer Progression. Gunduz M, Gunduz E. Breast Cancer-Focusing Tumor Microenvironment, Stem Cells and Metastasis. 2011; Rijeka, Croatia: INTECH Open Access Publisher:247-272. 
13. Houthuijzen JM, Daenen LG, Roodhart JM, Voest EE. The role of mesenchymal stem cells in anti-cancer drug resistance and tumour progression. Br J Cancer. 2012; 106:1901-1906.

14. Osborne CK, Schiff R. Mechanisms of endocrine resistance in breast cancer. Annu Rev Med. 2011; 62:233-247.

15. Girnita L, Worrall C, Takahashi S, Seregard S, Girnita A. Something old, something new and something borrowed: emerging paradigm of insulin-like growth factor type 1 receptor (IGF-1R) signaling regulation. Cell Mol Life Sci. 2014; 71:2403-2427.

16. Song RX, Chen Y, Zhang Z, Bao Y, Yue W, Wang JP, Fan P, Santen RJ. Estrogen utilization of IGF-1-R and EGF-R to signal in breast cancer cells. J Steroid Biochem Mol Biol. 2010; 118:219-230.

17. Casa AJ, Potter AS, Malik S, Lazard Z, Kuiatse I, Kim H, Tsimelzon A, Creighton CJ, Hilsenbeck SG, Brown PH, Oesterreich S, Lee AV. Estrogen and insulin-like growth factor-I (IGF-I) independently down-regulate critical repressors of breast cancer growth. Breast Cancer Res Treat. 2012; 132:61-73.

18. Foulstone EJ, Zeng L, Perks CM, Holly JM. Insulin-like growth factor binding protein 2 (IGFBP-2) promotes growth and survival of breast epithelial cells: novel regulation of the estrogen receptor. Endocrinology. 2013; 154:1780-1793.

19. Baxter RC. IGF binding proteins in cancer: mechanistic and clinical insights. Nat Rev Cancer. 2014; 14:329-341.

20. Sureshbabu A, Okajima H, Yamanaka D, Tonner E, Shastri S, Maycock J, Szymanowska M, Shand J, Takahashi S, Beattie J, Allan G, Flint D. IGFBP5 induces cell adhesion, increases cell survival and inhibits cell migration in MCF-7 human breast cancer cells. J Cell Sci. 2012; 125:1693-1705.

21. Cabodi S, del Pilar Camacho-Leal M, Di Stefano P, Defilippi P. Integrin signalling adaptors: not only figurants in the cancer story. Nat Rev Cancer. 2010; 10:858-870.

22. Wang W, Nag SA, Zhang R. Targeting the NFkappaB signaling pathways for breast cancer prevention and therapy. Curr Med Chem. 2015; 22:264-289.

23. Frasor J, El-Shennawy L, Stender JD, Kastrati I. NFkappaB affects estrogen receptor expression and activity in breast cancer through multiple mechanisms. Mol Cell Endocrinol. 2014; in press.

24. Zhou Y, Yau C, Gray JW, Chew K, Dairkee SH, Moore DH, Eppenberger U, Eppenberger-Castori S, Benz CC. Enhanced NF kappa B and AP-1 transcriptional activity associated with antiestrogen resistant breast cancer. BMC Cancer. 2007; 7:59.

25. Sas L, Lardon F, Vermeulen PB, Hauspy J, Van Dam P, Pauwels P, Dirix LY, Van Laere SJ. The interaction between ER and NFkappaB in resistance to endocrine therapy. Breast Cancer Res. 2012; 14:212.
26. Hayden MS, Ghosh S. Positive cross-talk between estrogen receptor and NF-kappaB in breast cancer. Cancer Res. 2009; 69:8918-8925.

27. Schuster M, Annemann M, Plaza-Sirvent C, Schmitz I. Atypical IkappaB proteins - nuclear modulators of NF-kappaB signaling. Cell Commun Signal. 2013; 11:23.

28. Pratt MA, Bishop TE, White D, Yasvinski G, Ménard M, Niu MY, Clarke R. Estrogen withdrawal-induced NF-kappaB activity and bcl-3 expression in breast cancer cells: roles in growth and hormone independence. Mol Cell Biol. 2003; 23:6887-6900.

29. Wakefield A, Soukupova J, Montagne A, Ranger J, French R, Muller WJ, Clarkson RW. Bcl3 selectively promotes metastasis of ERBB2-driven mammary tumors. Cancer Res. 2013; 73:745-755.

30. Pontiggia O, Sampayo R, Raffo D, Motter A, Xu R, Bissell MJ, Joffe EB, Simian M. The tumor microenvironment modulates tamoxifen resistance in breast cancer: a role for soluble stromal factors and fibronectin through beta1 integrin. Breast Cancer Res Treat. 2012; 133:459-471.

31. Shekhar MP, Santner S, Carolin KA, Tait L. Direct involvement of breast tumor fibroblasts in the modulation of tamoxifen sensitivity. Am J Pathol. 2007; 170:1546-1560.

32. Luo H, Yang G, Yu T, Luo S, Wu C, Sun Y, Liu M, Tu G. GPER-mediated proliferation and estradiol production in breast cancer-associated fibroblasts. Endocr Relat Cancer. 2014; 21:355-369.

33. Martinez-Outschoorn UE, Goldberg A, Lin Z, Ko YH, Flomenberg N, Wang C, Pavlides S, Pestell RG, Howell A, Sotgia F, Lisanti MP. Anti-estrogen resistance in breast cancer is induced by the tumor microenvironment and can be overcome by inhibiting mitochondrial function in epithelial cancer cells. Cancer Biol Ther. 2011; 12:924-938.

34. Rhodes LV, Muir SE, Elliott S, Guillot LM, Antoon JW, Penfornis P, Tilghman SL, Salvo VA, Fonseca JP, Lacey MR, Beckman BS, McLachlan JA, Rowan BG, Pochampally R, Burow ME. Adult human mesenchymal stem cells enhance breast tumorigenesis and promote hormone independence. Breast Cancer Res Treat. 2010; 121:293-300.

35. Dittmer A, Hohlfeld K, Lutzkendorf J, Muller LP, Dittmer J. Human mesenchymal stem cells induce E-cadherin degradation in breast carcinoma spheroids by activating ADAM10. Cell Mol Life Sci. 2009; 66:3053-3065.

36. Sasser AK, Sullivan NJ, Studebaker AW, Hendey LF, Axel AE, Hall BM. Interleukin-6 is a potent growth factor for ER-alpha-positive human breast cancer. Faseb J. 2007; 21:3763-3770.

37. Generali D, Berruti A, Brizzi MP, Campo L, Bonardi S, Wigfield S, Bersiga A, Allevi G, Milani M, Aguggini S, Gandolfi V, Dogliotti L, Bottini A, Harris AL, Fox SB. Hypoxia-inducible factor-1alpha expression predicts a poor response to primary chemoendocrine therapy and diseasefree survival in primary human breast cancer. Clin Cancer Res. 2006; 12:4562-4568. 
38. Sedlakova O, Svastova E, Takacova M, Kopacek J, Pastorek J, Pastorekova S. Carbonic anhydrase IX, a hypoxia-induced catalytic component of the $\mathrm{pH}$ regulating machinery in tumors. Front Physiol. 2014; 4:400.

39. Fagan DH, Uselman RR, Sachdev D, Yee D. Acquired resistance to tamoxifen is associated with loss of the type I insulin-like growth factor receptor: implications for breast cancer treatment. Cancer Res. 2012; 72:337233-337280.

40. Bundy DL, McKeithan TW. Diverse effects of BCL3 phosphorylation on its modulation of NF-kappaB p52 homodimer binding to DNA. J Biol Chem. 1997; 272:33132-33139.

41. Ahlqvist K, Saamarthy K, Syed Khaja AS, Bjartell A, Massoumi R. Expression of Id proteins is regulated by the Bcl-3 proto-oncogene in prostate cancer. Oncogene. 2013; 32:1601-1608.

42. Evdokimova V, Tognon CE, Benatar T, Yang WM, Krutikov K, Pollak M, Sorensen PH, Seth A. IGFBP7 Binds to the IGF-1 Receptor and Blocks Its Activation by InsulinLike Growth Factors. Science signaling. 2012; 18 :ra92.

43. Gyorffy B, Lanczky A, Eklund AC, Denkert C, Budczies J, Li Q, Szallasi Z. An online survival analysis tool to rapidly assess the effect of 22,277 genes on breast cancer prognosis using microarray data of 1,809 patients. Breast Cancer Res Treat. 2010; 123:725-731.

44. Akkiprik M, Feng YM, Wang $\mathrm{HH}$, Chen $\mathrm{K}, \mathrm{Hu} \mathrm{L}$, Sahin A, Krishnamurthy S, Ozer A, Hao X, Zhang W. Multifunctional roles of insulin-like growth factor binding protein 5 in breast cancer. Breast Cancer Res. 2008; 10:212.

45. Luther GA, Lamplot J, Chen X, Rames R, Wagner ER, Liu X, Parekh A, Huang E, Kim SH, Shen J, Haydon RC, He TC, Luu HH. IGFBP5 domains exert distinct inhibitory effects on the tumorigenicity and metastasis of human osteosarcoma. Cancer Lett. 2013; 336:222-230.

46. Akkiprik M, Hu L, Sahin A, Hao X, Zhang W. The subcellular localization of IGFBP5 affects its cell growth and migration functions in breast cancer. BMC Cancer. 2009; 9:103.

47. Tripathi G, Salih DA, Drozd AC, Cosgrove RA, Cobb LJ, Pell JM. IGF-independent effects of insulin-like growth factor binding protein-5 (Igfbp5) in vivo. FASEB J. 2009; 23:2616-2626.

48. Chen YJ, Yeh MH, Yu MC, Wei YL, Chen WS, Chen JY, Shih CY, Tu CY, Chen CH, Hsia TC, Chien PH, Liu SH, Yu YL, Huang WC. Lapatinib - induced NF-kappaB activation sensitizes triple-negative breast cancer cells to proteasome inhibitors. Breast Cancer Res. 2013; 15:R108.

49. Oida K, Matsuda A, Jung K, Xia Y, Jang H, Amagai Y, Ahn G, Nishikawa S, Ishizaka S, Jensen-Jarolim E, Matsuda H, Tanaka A. Nuclear factor-kB plays a critical role in both intrinsic and acquired resistance against endocrine therapy in human breast cancer cells. Sci Rep. 2014; 4:4057.

50. Larsen SL, Yde CW, Laenkholm AV, Rasmussen BB, Duun-Henriksen AK, Bak M, Lykkesfeldt AE,
Kirkegaard T. Aurora kinase B is important for antiestrogen resistant cell growth and a potential biomarker for tamoxifen resistant breast cancer. BMC Cancer. 2015; 15:239.

51. Kojima H, Kunimoto H, Inoue T, Nakajima K. The STAT3IGFBP5 axis is critical for IL-6/gp130-induced premature senescence in human fibroblasts. Cell Cycle. 2012; 11:730-739.

52. Gallo M, De Luca A, Lamura L, Normanno N. Zoledronic acid blocks the interaction between mesenchymal stem cells and breast cancer cells: implications for adjuvant therapy of breast cancer. Ann Oncol. 2012; 23:597-604.

53. Mao Y, Zhang Y, Qu Q, Zhao M, Lou Y, Liu J, Huang O, Chen X, Wu J, Shen K. Cancer-associated fibroblasts induce trastuzumab resistance in HER2 positive breast cancer cells. Mol Biosyst. 2015; 11:1029-1040.

54. Czekay RP, Wilkins-Port CE, Higgins SP, Freytag J, Overstreet JM, Klein RM, Higgins CE, Samarakoon R, Higgins PJ. PAI-1: An Integrator of Cell Signaling and Migration. Int J Cell Biol. 2011; 2011:562481.

55. Dellas C, Loskutoff DJ. Historical analysis of PAI-1 from its discovery to its potential role in cell motility and disease. Thromb Haemost. 2005; 93:631-640.

56. Camussi G, Deregibus MC, Bruno S, Cantaluppi V, Biancone L. Exosomes/microvesicles as a mechanism of cell-to-cell communication. Kidney Int. 2010; 78:838-848.

57. Kim HS, Choi DY, Yun SJ, Choi SM, Kang JW, Jung JW, Hwang D, Kim KP, Kim DW. Proteomic analysis of microvesicles derived from human mesenchymal stem cells. J Proteome Res. 2012; 11:839-849.

58. Frasor J, Weaver A, Pradhan M, Dai Y, Miller LD, Lin CY, Stanculescu A. Positive cross-talk between estrogen receptor and NF-kappaB in breast cancer. Cancer Res. 2009; 69:8918-8925.

59. Walter PL, Steinbrenner H, Barthel A, Klotz LO. Stimulation of selenoprotein $\mathrm{P}$ promoter activity in hepatoma cells by FoxOla transcription factor. Biochem Biophys Res Commun. 2008; 365:316-321.

60. Sarkissyan S, Sarkissyan M, Wu Y, Cardenas J, Koeffler HP, Vadgama JV. IGF-1 regulates Cyr61 induced breast cancer cell proliferation and invasion. PLoS One. 2014; 9:e103534.

61. Wu Y, Shang X, Sarkissyan M, Slamon D, Vadgama JV. FOXO1A is a target for HER2-overexpressing breast tumors. Cancer Res. 2010; 70:5475-5485.

62. Martens JW, Sieuwerts AM, Bolt-deVries J, Bosma PT, Swiggers SJ, Klijn JG, Foekens JA. Aging of stromalderived human breast fibroblasts might contribute to breast cancer progression. Thromb Haemost. 2003; 89:393-404.

63. Dittmer A, Fuchs A, Oerlecke I, Leyh B, Kaiser S, Martens JW, Lutzkendorf J, Muller L, Dittmer J. Mesenchymal stem cells and carcinoma-associated fibroblasts sensitize breast cancer cells in $3 \mathrm{D}$ cultures to kinase inhibitors. Int J Oncol. 2011; 39:689-696. 
64. Kirkegaard T, Hansen SK, Larsen SL, Reiter BE, Sorensen BS, Lykkesfeldt AE. T47D breast cancer cells switch from ER/HER to HER/c-Src signaling upon acquiring resistance to the antiestrogen fulvestrant. Cancer Lett. 2014; 344:90-100.

65. Dittmer A, Schunke D, Dittmer J. PTHrP promotes homotypic aggregation of breast cancer cells in threedimensional cultures. Cancer Lett. 2008; 260:56-61.

66. Oerlecke I, Bauer E, Dittmer A, Leyh B, Dittmer J. Cyclic AMP enhances TGFbeta responses of breast cancer cells by upregulating TGFbeta receptor I expression. PLoS One. 2013; 8:e54261.

67. Kessler J, Hahnel A, Wichmann H, Rot S, Kappler M, Bache M, Vordermark D. HIF-1alpha inhibition by siRNA or chetomin in human malignant glioma cells: effects on hypoxic radioresistance and monitoring via CA9 expression. BMC Cancer. 2010; 10:605. 